NATIONAL LABORATORY

\title{
October 2013
}

Prepared by

Diana E. Hun

Phillip W. Childs

Jerald A. Atchley

Andre O. Desjarlais

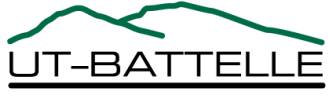

ORNL-27 (4-00) 


\section{DOCUMENT AVAILABILITY}

Reports produced after January 1, 1996, are generally available free via the U.S. Department of Energy (DOE) Information Bridge.

Web site http://www.osti.gov/bridge

Reports produced before January 1, 1996, may be purchased by members of the public from the following source.

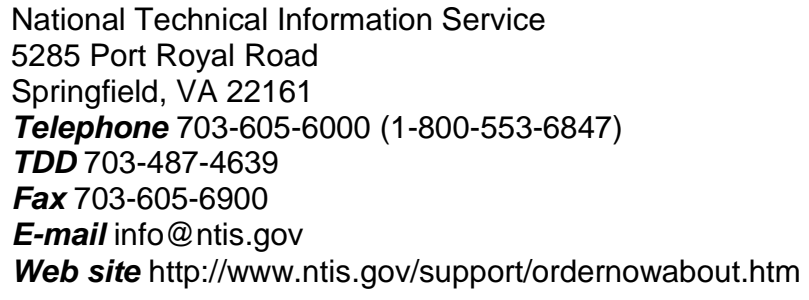

Reports are available to DOE employees, DOE contractors, Energy Technology Data Exchange (ETDE) representatives, and International Nuclear Information System (INIS) representatives from the following source.

Office of Scientific and Technical Information

P.O. Box 62

Oak Ridge, TN 37831

Telephone 865-576-8401

Fax 865-576-5728

E-mail reports@osti.gov

Web site http://www.osti.gov/contact.html

This report was prepared as an account of work sponsored by an agency of the United States Government. Neither the United States Government nor any agency thereof, nor any of their employees, makes any warranty, express or implied, or assumes any legal liability or responsibility for the accuracy, completeness, or usefulness of any information, apparatus, product, or process disclosed, or represents that its use would not infringe privately owned rights. Reference herein to any specific commercial product, process, or service by trade name, trademark, manufacturer, or otherwise, does not necessarily constitute or imply its endorsement, recommendation, or favoring by the United States Government or any agency thereof. The views and opinions of authors expressed herein do not necessarily state or reflect those of the United States Government or any agency thereof. 
Energy and Transportation Science Division

\title{
Effects from the Reduction of Air Leakage on Energy and Durability
}

\author{
Diana E. Hun \\ Phillip W. Childs \\ Jerald A. Atchley \\ Andre O. Desjarlais
}

Date Published: October 2013

Prepared by

OAK RIDGE NATIONAL LABORATORY

Oak Ridge, Tennessee 37831-6283

managed by

UT-BATTELLE, LLC

for the

U.S. DEPARTMENT OF ENERGY

under contract DE-AC05-00OR22725 


\section{Content}

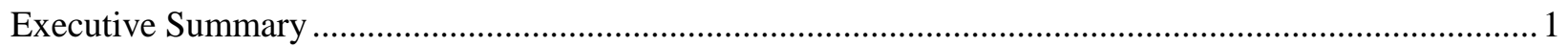

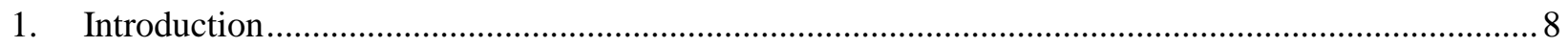

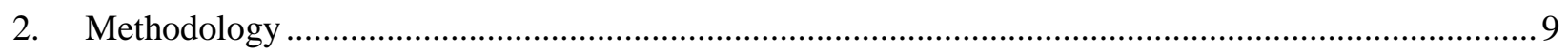

2.1 Building Envelope Systems Testing (BEST) Laboratory ...................................................... 9

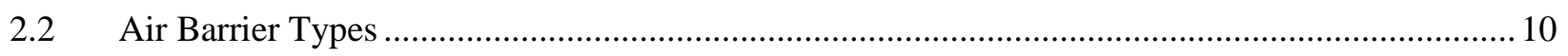

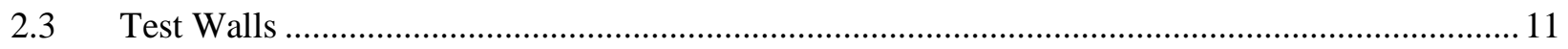

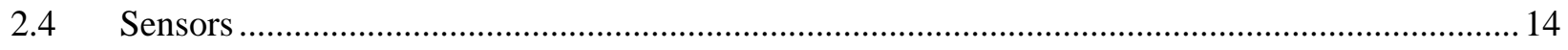

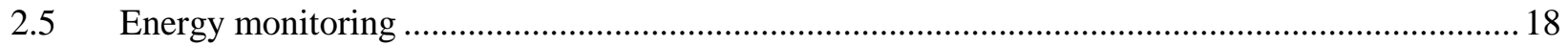

2.6 Characterization of the air leakage of the test walls ................................................................. 19

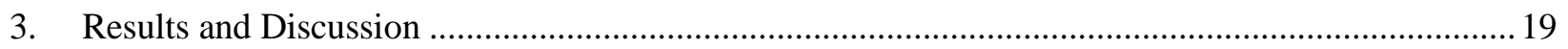

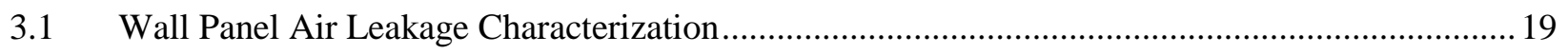

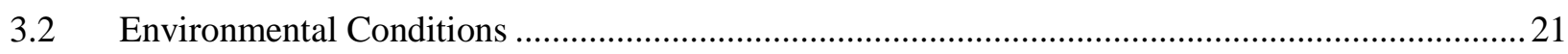

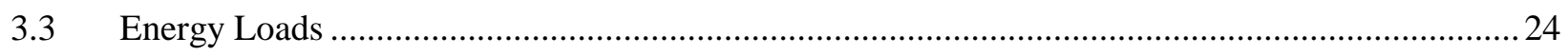

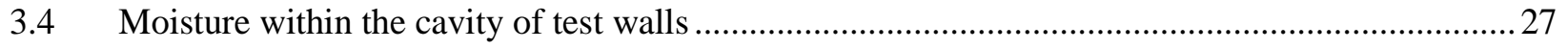

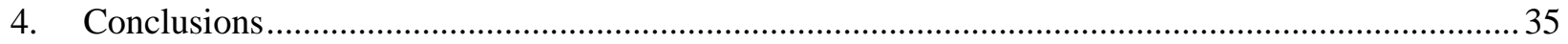

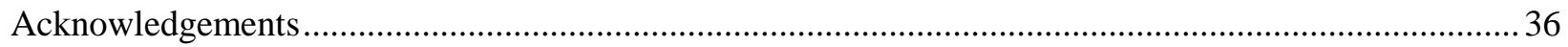

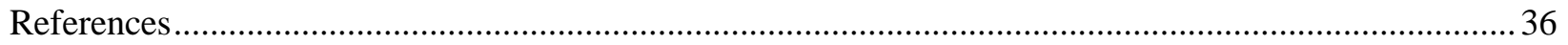




\section{List of Figures}

Figure 1. Air leakage rates from field studies. A: residential buildings. B: commercial buildings......... 8

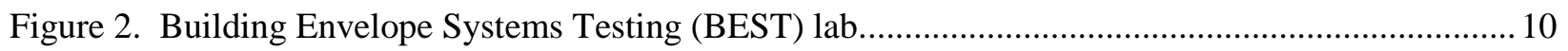

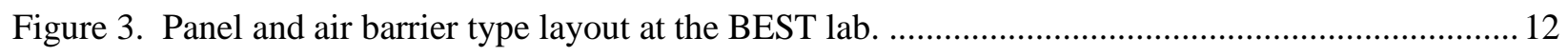

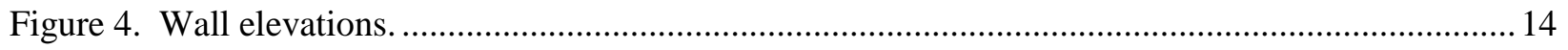

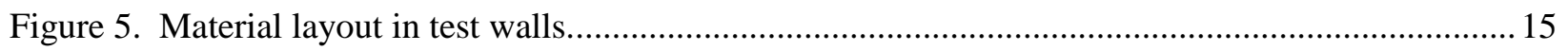

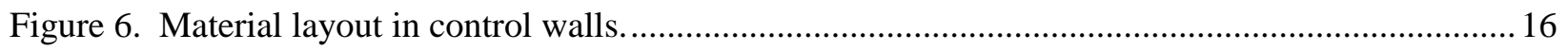

Figure 7. Panel groups with added imperfections and 12-month average air leakage rates at $75 \mathrm{~Pa} . \ldots \ldots . .17$

Figure 8. General sensor layout within the center-stud cavity of test walls.......................................... 18

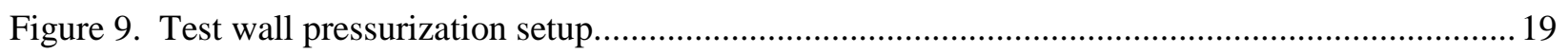

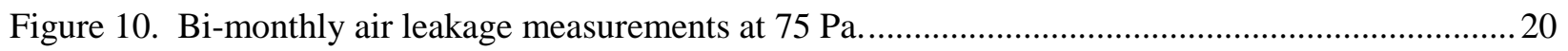

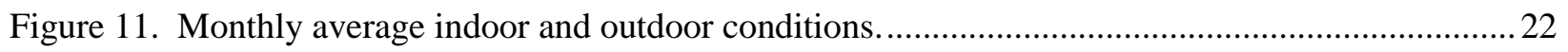

Figure 12. Monthly average wind speeds measured at the weather station located in the grounds of the

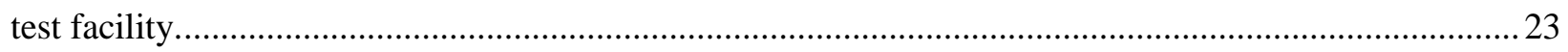

Figure 13. Monthly average outdoor-to-indoor building pressure differentials.....................................2 23

Figure 14. Heat flux at $1 / 4$ height and $1 / 2$ height of the Group 4 panels during the heating season and

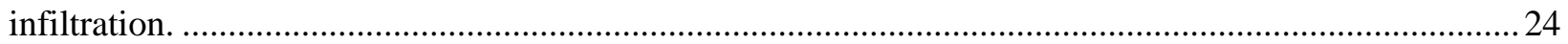

Figure 15. January measurements. A: South and north wind speeds; B: Outdoor-to-indoor pressure differentials (positive values $=\mathrm{P}_{\text {out }}>\mathrm{P}_{\text {in }}$ ); C: Heat flux from Group 4 walls measured between facing of fiberglass insulation and interior drywall and at $1 / 4$ height of wall.......................................................26 Figure 16. Heat fluxes between facing of fiberglass insulation and interior drywall of the Group 4 walls. A: Effect of infiltration on heat flux. B: Effect of exfiltration on heat flux.........................................26 Figure 17. Temperatures measured between the fiberglass insulation and its facing in the Group 4 walls

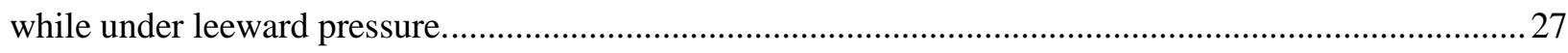

Figure 18. Monthly average temperatures at the inner surface of exterior sheathings. ..........................28

Figure 19. Monthly average humidity ratio and water vapor pressure at the inner surface of exterior sheathings

Figure 20. January hourly average humidity ratio at the inner surface of exterior sheathings in Level 1 walls. A: East and north-facing walls: Groups 3, 5,7 and 8. B: South-facing walls: Groups 2 and 4. ...31 Figure 21. Adsorption isotherms of oriented strand board sheathing and glass mat gypsum sheathing.... 31 Figure 22. Monthly average relative humidity at the inner surface of exterior sheathings......................33 Figure 23. January hourly average relative humidity at the inner surface of the exterior sheathings in the Group 3, 5, 7 and 8 panels.

Figure 24. January and February hourly averages from Level 1 walls in Groups 3, 5, 7 and 8 with respect to the lowest isopleth for mold growth on organic substrates (LIM B I) and inorganic substrates (LIM B II).

Figure 25. January and February hourly averages from Level 1 walls from Groups 1, 2, 4 and 6 with respect to the lowest isopleth for mold growth on organic substrates (LIM B I) and inorganic substrates (LIM B II). 


\section{List of Tables}

Table 1. Air barrier types and materials evaluated in this study.......................................................... 10

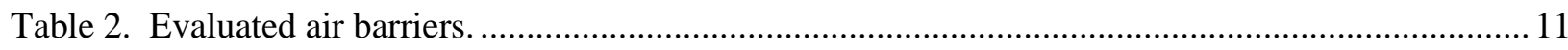

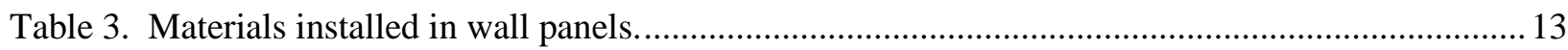

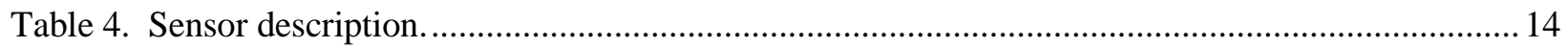

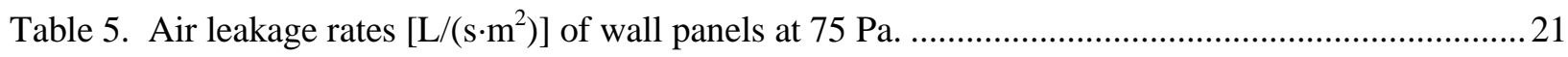

Table 6. Monthly increases in heat flux in Group 4 panels due to infiltration.........................................25 


\section{Executive Summary}

Buildings are responsible for approximately $40 \%$ of the energy used in the US. Codes have been increasing building envelope requirements, and in particular those related to improving airtightness, in order to reduce energy consumption. The main goal of this research was to evaluate the effects from reductions in air leakage on energy loads and material durability. To this end, we focused on the airtightness and thermal resistance criteria set by the 2012 International Energy Conservation Code (IECC). Requirements from the 2012 IECC will be setting the path for construction practices across the nation for some time given the slow adoption rate of new codes. As of September 2013, the 2012 IECC has been adopted fully or with limitations by only seven states.

To meet our goal, we conducted field assessments at the Building Envelope Systems Testing (BEST) facility in Syracuse, NY, which is located in DOE climate zone 5. This site was selected because building envelopes in cold climates tend to be more susceptible to potential moisture problems. Table ES1 describes the eight groups of walls we installed and Figure ES 1 shows the material layout in the test walls. Each group utilized one of the air barrier types commonly used in the US, and emulated either residential wood-framing or commercial steel-framing construction. Each group was made of three panels that were constructed with the same materials, but had an air leakage rate that was somewhat close to one of these levels:

- Level $1 \cong 0.02 \mathrm{~L} /\left(\mathrm{s} \cdot \mathrm{m}^{2}\right)$ at $75 \mathrm{~Pa}$

- Level $2 \cong 0.2 \mathrm{~L} /\left(\mathrm{s} \cdot \mathrm{m}^{2}\right)$ at $75 \mathrm{~Pa}$

- Level $3 \cong 1 \mathrm{~L} /\left(\mathrm{s} \cdot \mathrm{m}^{2}\right)$ at $75 \mathrm{~Pa}$

These air leakage levels are based on the air barrier compliance options set by the 2012 IECC for commercial buildings. These options are that at a pressure differential of $75 \mathrm{~Pa}$ :

1. Air barrier materials shall have an air leakage rate that is less than $0.02 \mathrm{~L} /\left(\mathrm{s} \cdot \mathrm{m}^{2}\right)$;

2. Air barrier assemblies shall have an air leakage rate that is less than $0.2 \mathrm{~L} /\left(\mathrm{s} \cdot \mathrm{m}^{2}\right)$; or

3. The building enclosure shall have an air leakage rate that is less than $2 \mathrm{~L} /\left(\mathrm{s} \cdot \mathrm{m}^{2}\right)$

Levels 1 and 2 are significantly lower than the IECC requisites for the building enclosure because we wanted to investigate the effects from stricter airtightness requirements that could be enacted in the future.

As indicated in Figure ES1, the assessed walls had insulation with a thermal resistance of 3.7 $\mathrm{K} \cdot \mathrm{m}^{2} / \mathrm{W}\left(\mathrm{R}_{\mathrm{US}}=21 \mathrm{~h} \cdot \mathrm{ft}^{2} \cdot{ }^{\circ} \mathrm{F} / \mathrm{Btu}\right)$, which put them at the lower end of what is considered as high- $\mathrm{R}$ walls $\left(\sim 3.2<\mathrm{R}_{\mathrm{SI}}<\sim 7 \mathrm{~K} \cdot \mathrm{m}^{2} / \mathrm{W}, \sim 18<\mathrm{R}_{\mathrm{US}}<\sim 40 \mathrm{~h} \cdot \mathrm{ft}^{2} \cdot{ }^{\circ} \mathrm{F} / \mathrm{Btu}\right)$. All of the panel assemblies included exterior continuous insulation, which is an IECC requirement for commercial buildings located in climate zone 5, and is one of two insulation options for residential buildings. Most of the walls used $3.8 \mathrm{~cm}$-thick extruded polystyrene $(\mathrm{XPS})$ foam boards $\left(\mathrm{R}_{\mathrm{SI}}=1.3 \mathrm{~K} \cdot \mathrm{m}^{2} / \mathrm{W}, \mathrm{R}_{\mathrm{US}}=\right.$ $\left.7.5 \mathrm{~h} \cdot \mathrm{ft}^{2} \cdot{ }^{\circ} \mathrm{F} / \mathrm{Btu}\right)$ as exterior insulation, and faced-fiberglass batts in the wall cavity $\left(\mathrm{R}_{\mathrm{SI}}=2.4\right.$ $\left.\mathrm{K} \cdot \mathrm{m}^{2} / \mathrm{W}, \mathrm{R}_{\mathrm{US}}=13 \mathrm{~h} \cdot \mathrm{ft}^{2} \cdot{ }^{\circ} \mathrm{F} / \mathrm{Btu}\right)$. Three had $\sim 7.6 \mathrm{~cm}$-thick closed-cell foam as exterior insulation $\left(\mathrm{R}_{\mathrm{SI}} \cong 3.7 \mathrm{~K} \cdot \mathrm{m}^{2} / \mathrm{W}, \mathrm{R}_{\mathrm{US}} \cong 21 \mathrm{~h} \cdot \mathrm{ft}^{2} \cdot{ }^{\circ} \mathrm{F} / \mathrm{Btu}\right)$. 
Indoor conditions at the BEST lab were set to $20^{\circ} \mathrm{C}$ and $40 \%$ relative humidity throughout the twelve-month evaluation. This high relative humidity can occur in a cold climate during the winter, especially in buildings with an airtight envelope and inadequate mechanical ventilation. Temperature, relative humidity, moisture content, pressure differentials, and heat flux were monitored at various locations within the stud cavity of the test walls. Temperature, relative humidity, wind speed and direction, and solar radiation measurements were gathered from the onsite weather station. Data collection began on November 2011 and ended on October 2012.

Table ES 1. Evaluated wall groups and their air barrier types.

\begin{tabular}{|c|c|c|c|c|}
\hline $\begin{array}{l}\text { Wall } \\
\text { Group }\end{array}$ & Air Barrier Type & Installed Air Barrier & $\begin{array}{l}\text { Location of Air Barrier in } \\
\text { Wall Assembly }\end{array}$ & Framing \\
\hline 1 & Spray-applied foam & $7.6 \mathrm{~cm}$-thick closed-cell foama & Outer side of exterior sheathing & Steel \\
\hline 2 & $\begin{array}{l}\text { Mechanically- } \\
\text { fastened membrane }\end{array}$ & Cross-woven polyolefin membrane ${ }^{a}$ & Outer side of exterior sheathing & Steel \\
\hline 3 & Insulating sheathing & $\begin{array}{l}3.8 \mathrm{~cm} \text {-thick XPS rigid foam (acted as } \\
\text { exterior sheathing)a }^{\text {a }}\end{array}$ & Outer side of stud cavity & Steel \\
\hline 4 & $\begin{array}{l}\text { Non-insulating } \\
\text { sheathing }\end{array}$ & OSB with built-in overlaya & Outer side of stud cavity & Wood \\
\hline 5 & $\begin{array}{l}\text { Sealant w/ backup } \\
\text { structure }\end{array}$ & OSB with sealed edges ${ }^{b}$ & Outer side of stud cavity & Wood \\
\hline 6 & Interior air barrier & $\begin{array}{l}\text { Polyamide membrane that changed its } \\
\text { water vapor permeability with ambient } \\
\text { humidityb }\end{array}$ & Inner side of stud cavity & Wood \\
\hline 7 & $\begin{array}{l}\text { Fluid-applied } \\
\text { membranes }\end{array}$ & Vapor permeable (>10 perms) $)^{a}$ & Outer side of exterior sheathing & Steel \\
\hline 8 & $\begin{array}{l}\text { Self-adhered } \\
\text { membrane }\end{array}$ & Vapor permeable (>10 perms) $)^{a}$ & Outer side of exterior sheathing & Steel \\
\hline
\end{tabular}

Abbreviations: OSB, oriented strand board; XPS, extruded polystyrene.

a. Air barrier also acted as the water-resistive barrier.

b. A cross-woven polyolefin wrap with breathable polyolefin coating was installed as the water-resistive barrier. 

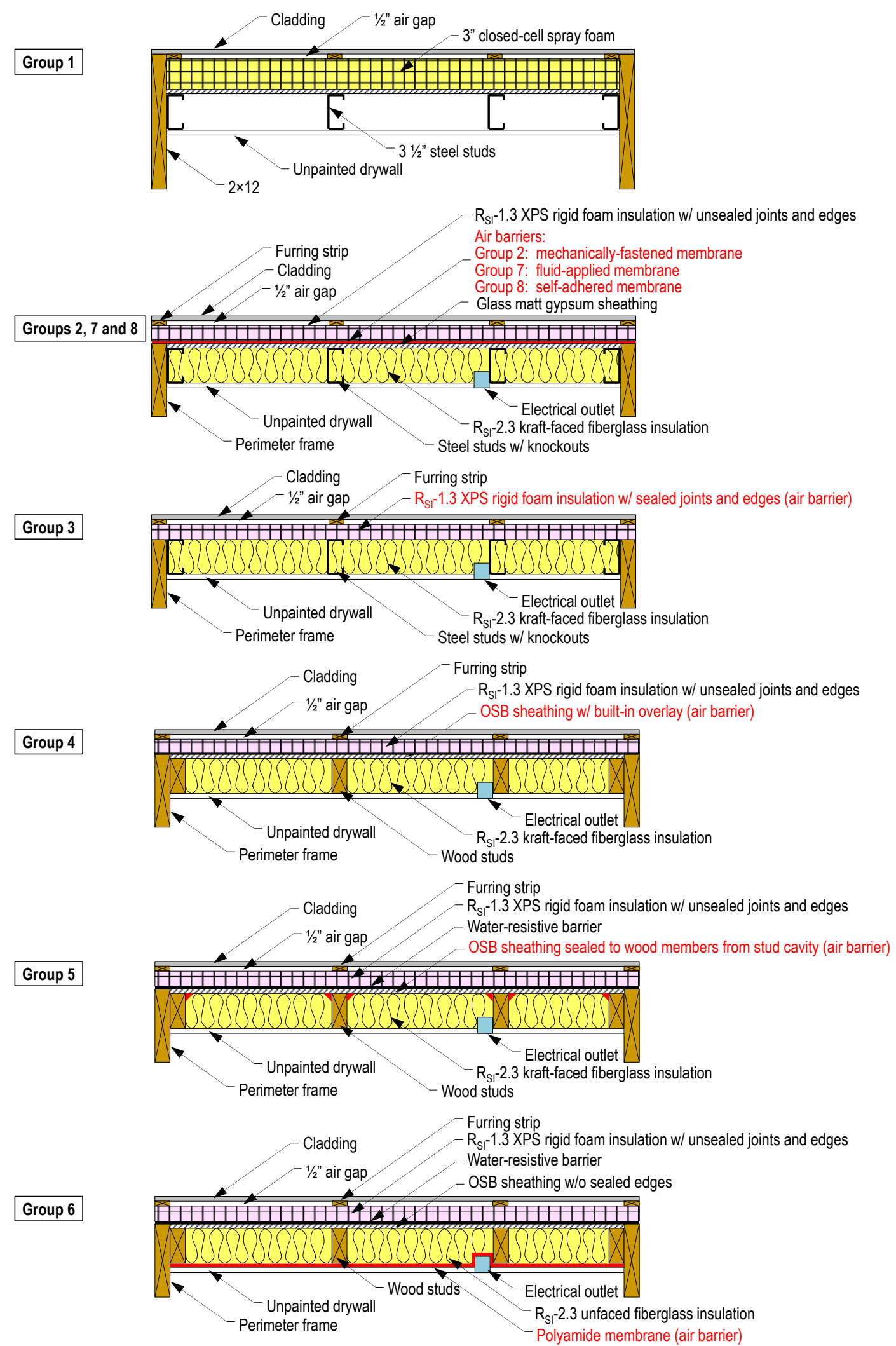

Figure ES 1. Material layout in test walls. 
Effects on energy loads from the reduction of air leakage were most noticeable on walls that were facing south because wind from this direction was dominant. Furthermore, heat flux measurements were the highest during the winter because of larger indoor-to-outdoor temperature differentials. Figure ES2 shows data from the south-facing Group 4 panels that were gathered during infiltration (i.e., outdoor pressure $>$ indoor pressure). Heat fluxes in the Level 1 panel were mostly due to conduction because of its high airtightness (i.e., $<0.02$ $\mathrm{L} /\left(\mathrm{s} \cdot \mathrm{m}^{2}\right)$ at $\left.75 \mathrm{~Pa}\right)$. Therefore, increases in flux in the Level 2 and Level 3 walls, when compared to the Level 1 panel, were due to air leakage. Maximum differences between the Level 3 (1340 $\left.\mathrm{W} \cdot \mathrm{h} / \mathrm{m}^{2}\right)$ and Level $1\left(930 \mathrm{~W} \cdot \mathrm{h} / \mathrm{m}^{2}\right)$ walls occurred in December and January. During these months, the average indoor-to-outdoor temperature difference was $20^{\circ} \mathrm{C}$, and the $95^{\text {th }}$ percentile outdoor-to-indoor pressure was about $19 \mathrm{~Pa}$. Table ES2 summarizes the percent increases and indicates that the Level 3 panel had fluxes that were up to $54 \%$ higher than those from the Level 1 wall. In contrast, differences between the Level $2\left(1010 \mathrm{~W} \cdot \mathrm{h} / \mathrm{m}^{2}\right)$ and the Level 1 panels did not exceed $11 \%$, which indicates that the energy-related benefits from decreasing air leakage from 0.2 to $0.02 \mathrm{~L} /\left(\mathrm{s} \cdot \mathrm{m}^{2}\right)$ at $75 \mathrm{~Pa}$ may not be sufficient to justify the additional effort. These percent differences were influenced by the relatively high insulation in the walls; that is, if a lower R-value had been used, then the relative contribution from airflow to heat flux would have been less.

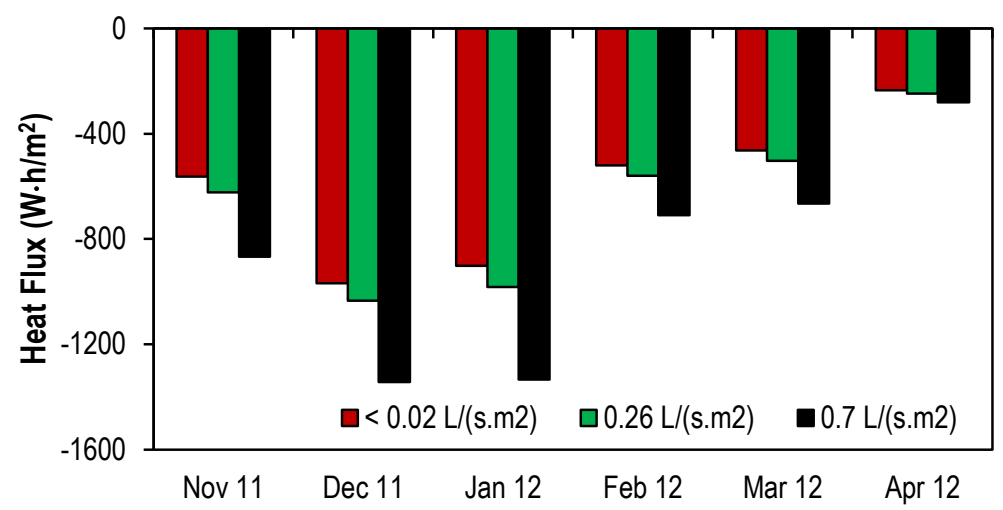

Figure ES 2. Average heat flux through the Group 4 panels during the heating season and infiltration. a. Fluxes were measured at mid-height of the wall, between the facing of the fiberglass insulation and the interior drywall.

b. Air leakage rates shown were measured at $\triangle \mathrm{P}=75 \mathrm{~Pa}$.

Table ES 2. Monthly increases in heat flux in Group 4 panels due to infiltration.

\begin{tabular}{ccccccc}
\hline \multirow{2}{*}{ Compared air leakage levels } & Nov & Dec & Jan & Feb & Mar & Apr \\
\cline { 2 - 7 } & 54 & 39 & 48 & 37 & 44 & 19 \\
\hline Level 3 vs. Level 1 & 39 & 30 & 36 & 27 & 32 & 14 \\
Level 3 vs. Level 2 & 11 & 7 & 9 & 7 & 9 & 5 \\
Level 2 vs. Level 1 & & & & &
\end{tabular}


In addition to energy loads, we also investigated the potential for mold growth. We focused on the Level 1 walls because the airflow paths in the Level 2 and Level 3 panels varied depending on their group, and this difference influenced temperature and relative humidity within the wall cavities. Our criteria for mold occurrence are the lowest isopleths for mold (LIM) growth per Sedlbauer (2002):

- LIM B I: biologically recyclable building materials like wall paper, paper facings on gypsum board, building materials made of biologically degradable raw materials, material for permanent caulking.

- LIM B II: building materials with porous structure such as renderings, minerals building materials, certain wood species as well as insulation material not covered by LIM B I.

Conditions above these isopleths indicate that mold growth may be possible, but additional evaluations are required to reach a more decisive conclusion.

Figure ES3 shows January and February hourly relative humidity and temperature measurements. These data were gathered at the inner surface of exterior sheathings (i.e., glass mat gypsum, XPS or oriented strand board), which is an area that tends to be susceptible to the occurrence of mold. Figure ES3 indicates how these measurements relate to the LIMs. Main factors that affected these results are:

a. Indoor relative humidity: set to $40 \%$, which can be reached in buildings with tightly-built envelopes and inadequate ventilation.

b. Winter insolation: walls facing south (Group 2 and 4) were exposed to higher winter solar radiation; consequently, their wall cavities benefitted from warmer temperatures that lowered the relative humidity, and solar-driven diffusion that dried the wall cavities toward the indoor space.

c. Moisture capacity of materials framing the wall cavities: walls framed with steel studs and either XPS rigid foam (Group 3) or glass mat gypsum (Groups 7 and 8) had a higher likelihood for mold growth than walls that utilized wood studs and oriented strand board (Group 5). Given that all of these panels were facing either east or north and received minimal winter insolation, the difference in mold growth potential is due to the fact that wood products have a moisture capacity that is at least an order of magnitude higher than that of XPS, glass mat gypsum and steel. This higher capacity dampens increases in moisture within the wall cavity. Furthermore, the Group 3 walls experienced condensation much more frequently than the Group 7 and the Group 8 panels because the moisture capacity of XPS is lower than that of glass mat gypsum.

d. R-value of continuous exterior insulation: exterior insulation values in the Group 1 walls were about three times higher than in the other panels. This higher thermal resistance maintained the wall cavity of the Group 1 walls at a warmer temperature and lower relative humidity, which were not conducive for mold growth. 
e. Location of air barrier: the Group 6 walls maintained relative humidity values within its cavity that were below $75 \%$ even though it was facing north and received minimal solar radiation. The likely explanation is that the relatively dry outdoor air regulated the $\mathrm{RH}$ levels in the cavity given that the air barrier was on the interior side of the wall, which allowed for outdoor air to easily flow into the wall. The role of the inner polyamide membrane as a vapor retarder $\left(4.3 \times 10^{-11} \mathrm{~kg} /\left(\mathrm{m}^{2} \cdot \mathrm{s} \cdot \mathrm{Pa}\right), 0.75 \mathrm{perms}\right)$ in the Group 6 walls may have played a secondary part because the Group 5 walls, which had a similar construction (wood-framed and interior vapor retarder $\left(\mathrm{kraft}\right.$ paper $=5.7 \times 10^{-11}$ $\mathrm{kg} /\left(\mathrm{m}^{2} \cdot \mathrm{s} \cdot \mathrm{Pa}\right), 1$ perm $\left.)\right)$ experienced higher $\mathrm{RH}$ levels due to the exterior air barrier hindrance of dry outdoor air flow into the cavity.

Table ES3 summarizes the effects from factors that increased the likelihood of mold incidence. This summary suggests that winter indoor moisture levels should be overseen in buildings with a tightly-built envelope. If high indoor relative humidity is likely to occur in the winter, then the design of east, west and north-facing walls need extra scrutiny to reduce the possibility of mold growth. Findings suggest that under the studied conditions, adding kraft paper as an interior vapor semi-impermeable layer may not sufficiently reduce diffusion into wall cavities to adequately control water vapor levels within these spaces.

Table ES 3. Parameters that influenced risk for mold growth in a cold climate during the winter.

\begin{tabular}{|c|c|c|c|c|c|c|}
\hline $\begin{array}{l}\text { Wall } \\
\text { Group }\end{array}$ & $\begin{array}{l}\text { Indoor } \\
\text { Relative } \\
\text { Humidity }\end{array}$ & Winter Insolation & $\begin{array}{c}\text { Moisture Capacity } \\
\text { of Materials }\end{array}$ & Exterior Insulation & $\begin{array}{c}\text { Location of Air } \\
\text { Barrier }\end{array}$ & $\begin{array}{c}\text { Risk of } \\
\text { Mold Growth }\end{array}$ \\
\hline 1 & $\sim 40 \%$ & Low (west-facing) & Low (GMG) & $\operatorname{High}\left(3.7 \mathrm{~K} \cdot \mathrm{m}^{2} \mathrm{~W}\right)$ & Exterior & Unlikely \\
\hline 2 & $\sim 40 \%$ & High (south-facing) & Low (GMG) & $\operatorname{Med}\left(1.3 \mathrm{~K} \cdot \mathrm{m}^{2} \mathrm{~W}\right)$ & Exterior & Unlikely \\
\hline 3 & $\sim 40 \%$ & Low (east-facing) & Very low (XPS) & $\operatorname{Med}\left(1.3 \mathrm{~K} \cdot \mathrm{m}^{2} / \mathrm{W}\right)$ & Exterior & Some $^{a}$ \\
\hline 4 & $\sim 40 \%$ & High (south-facing & High (OSB) & $\operatorname{Med}\left(1.3 \mathrm{~K} \cdot \mathrm{m}^{2} \mathrm{~W}\right)$ & Exterior & Unlikely \\
\hline 5 & $\sim 40 \%$ & Low (east-facing) & High (OSB) & $\operatorname{Med}\left(1.3 \mathrm{~K} \cdot \mathrm{m}^{2} / \mathrm{W}\right)$ & Exterior & Unlikely \\
\hline 6 & $\sim 40 \%$ & Low (north-facing) & High (OSB) & $\operatorname{Med}\left(1.3 \mathrm{~K} \cdot \mathrm{m}^{2} \mathrm{~W}\right)$ & Interior & Unlikely \\
\hline 7 & $\sim 40 \%$ & Low (east-facing) & Low (GMG) & $\operatorname{Med}\left(1.3 \mathrm{~K} \cdot \mathrm{m}^{2} / \mathrm{W}\right)$ & Exterior & Some $^{a}$ \\
\hline 8 & $\sim 40 \%$ & Low (north-facing) & Low (GMG) & $\operatorname{Med}\left(1.3 \mathrm{~K} \cdot \mathrm{m}^{2} \mathrm{~W}\right)$ & Exterior & Some $^{a}$ \\
\hline
\end{tabular}

Abbreviations: cc, closed-cell foam; GMG, glass mat gypsum sheathing; OSB, oriented strand board; XPS, extruded polystyrene insulation board.

a. Requires further analysis. 

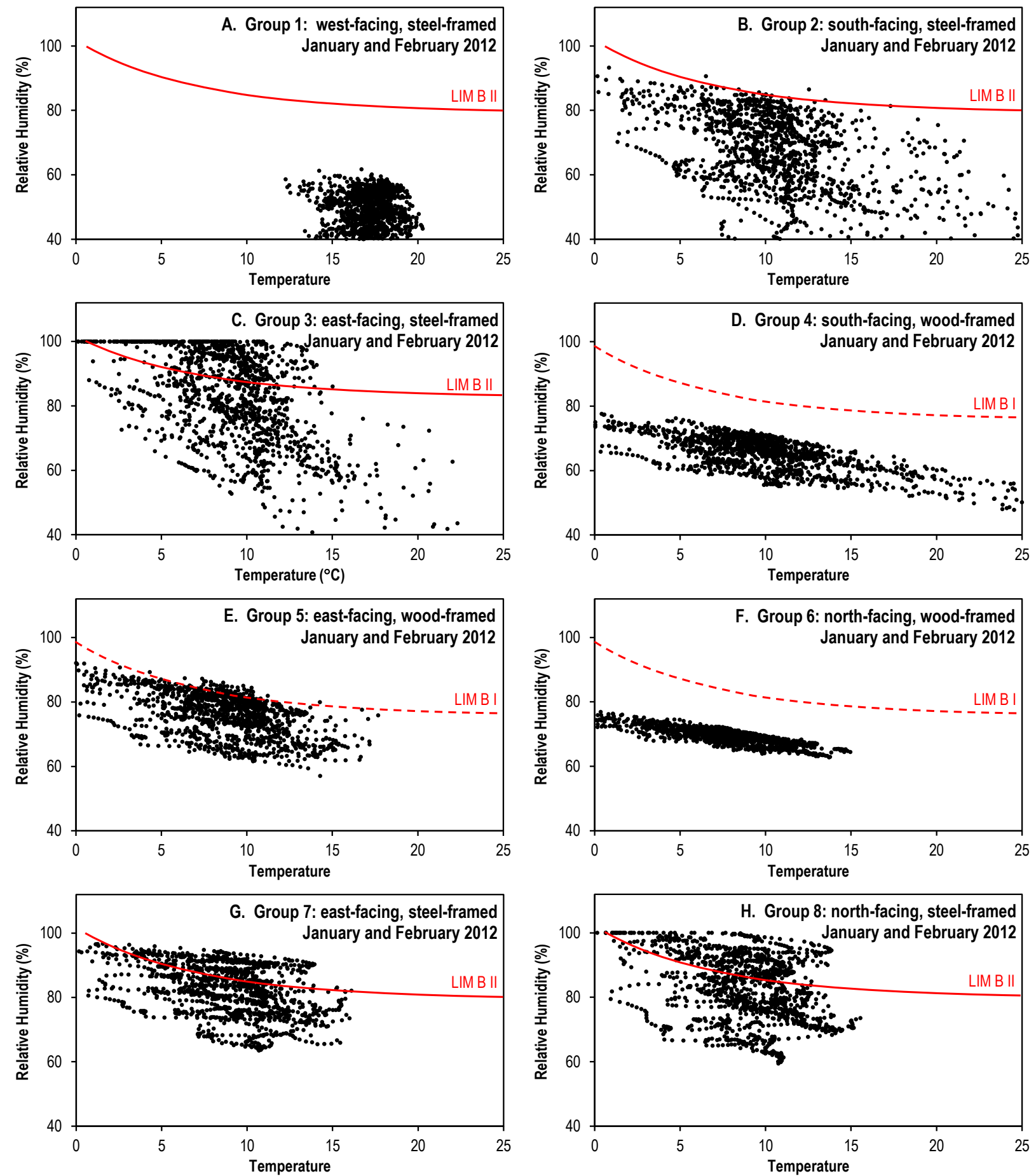

Figure ES 3. January and February hourly averages from Level 1 walls with respect to the lowest isopleth for mold growth on organic substrates (LIM B I) and inorganic substrates (LIM B II). 


\section{Introduction}

Air leakage through the building envelope can affect energy consumption, material durability and indoor air quality. Infiltration and exfiltration can be a significant contributor to heating, ventilation, and air conditioning (HVAC) loads. Huang et al. (1999) estimated these loads to be $28 \%$ and $16 \%$ of the heating loads and cooling loads in homes, respectively. In commercial buildings, this contribution is approximately $18 \%$ of the heating loads (Huang and Franconi 1999). Additionally, the flow of moisture-laden air can compromise the durability of materials and/or promote the growth of mold and mildew within the building envelope (TenWolde and Rose 1996). Logue et al. (2013) estimated that improving the airtightness of all US homes at average retrofit performance levels could decrease nationwide residential energy use by 0.7 quads or $7 \%$. Emmerich et al. (2005) simulated commercial buildings in five US cities and estimated a reduction of 3 to $36 \%$ in annual heating and cooling energy costs due to increased airtightness.

Airtightness requirements in building codes have become stricter because of the aforementioned problems caused by air leakage. Figure 1 illustrates the requisites set by the 2012 International Energy Conservation Code (IECC), and how these values compare to data from field studies. According to Figure 1, construction practices in the residential sector have been improving; nevertheless, efforts will have to be furthered to meet IECC. Fewer data are available on the commercial side. A literature survey by Emmerich et al. (2005) suggests that, on average, commercial buildings have air leakage rates of $9 \mathrm{~L} /\left(\mathrm{s} \cdot \mathrm{m}^{2}\right)$ at $75 \mathrm{~Pa}$, which is 4.5 times higher than what is specified by the IECC. Note that this code provides two options to the building enclosure airtightness requirement of $2 \mathrm{~L} /\left(\mathrm{s} \cdot \mathrm{m}^{2}\right)$ at $75 \mathrm{~Pa}$ : a) use of an air barrier material that has an air permeance that is lower than $0.02 \mathrm{~L} /\left(\mathrm{s} \cdot \mathrm{m}^{2}\right)$ at $75 \mathrm{~Pa}$ per ASTM E2178, or b) use of an air barrier assembly that has an air leakage that is lower than $0.2 \mathrm{~L} /\left(\mathrm{s} \cdot \mathrm{m}^{2}\right)$ at $75 \mathrm{~Pa}$ per ASTM E2357. These lenient alternatives are based on the fact that measuring the air leakage of large commercial buildings remains an onerous endeavor.
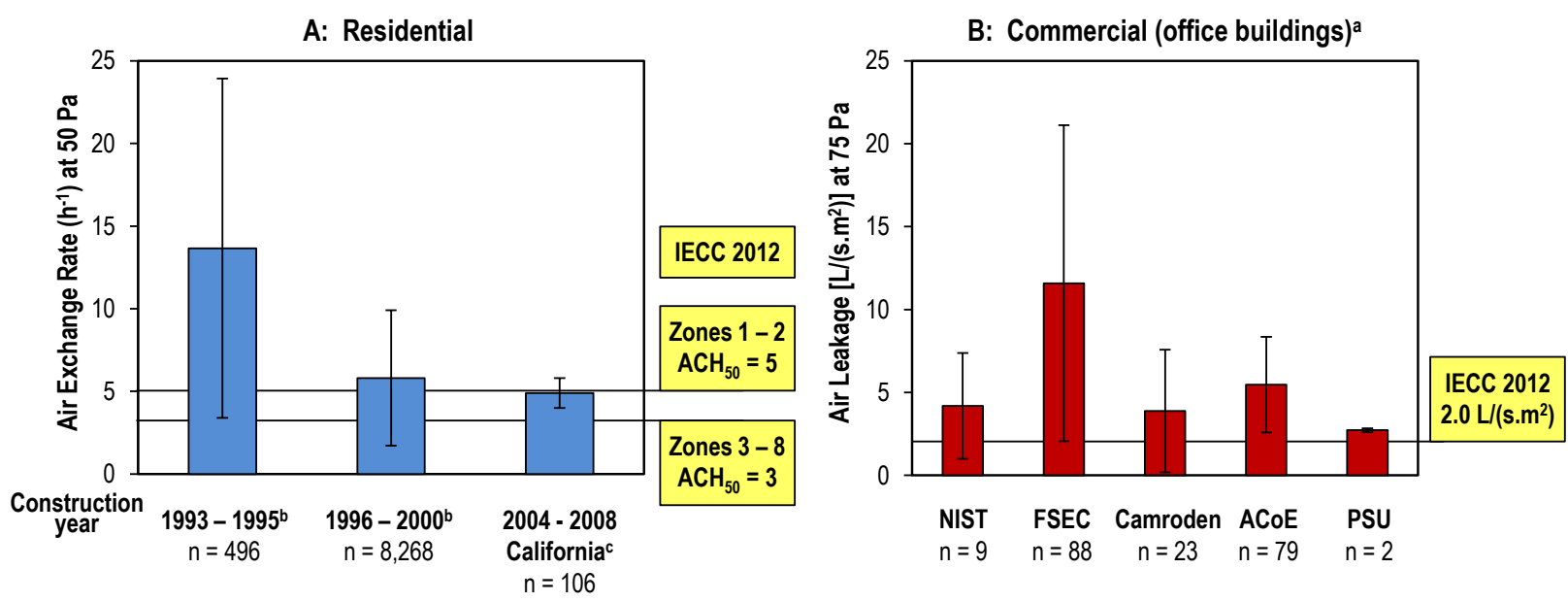

Figure 1. Air leakage rates from field studies. A: residential buildings. B: commercial buildings.

Whiskers denote standard deviations.

References: a. Emmerich and Persily (2005); b, Sherman and Matson (2002); c. Offerman (2009).

Abbreviations: ACoE, Army Corp of Engineers; FSEC, Florida Solar Energy Center; NIST, National Institute of Standards and Technology; PSU, Penn State University. 
Most field evaluations of airtightness have been short-term assessments that primarily focused on comparing air leakage rates through the building envelope before and after retrofits, or from buildings with and without an air barrier. Wilcox (2001) and Weston (2006) reported reductions in infiltration due to the installation of housewraps in new residential construction. Boudreaux et al. (2012) and Jackson et al. (2012) documented decreases in air leakage rates during residential retrofits. Similarly, Zhivov and Herron (2011) described air leakage conditions before and after the retrofit of US Army buildings. Given that these studies show that significant reductions in air leakage are attainable, the goal of this project was to improve our understanding of the effects of decreases in air leakage on energy loads and potential moisture problems through field experiments. The main difference between the work conducted in this research and somewhat similar field evaluations (Tsongas and Nelson 1991, TenWolde and Carll 1992) is that we utilized higher thermal insulation as well as exterior continuous insulation due to stricter building codes requirements. Moreover, most of the previous work on high-R walls addressed moisture concerns through computer simulations instead of field data (Straube and Smegal 2012). We conducted a twelve-month test at the Building Envelope Systems Testing (BEST) laboratory in Syracuse, NY, which is in DOE Zone 5. This facility was selected because building envelopes that are located in cold climates are potentially more susceptible to moisture problems. We installed 28 wall panels at the BEST lab, and varied the following parameters in the test walls:
a. Building materials: test specimens were representative of residential and commercial construction
b. Air leakage rate
c. Air barrier type: installed the eight air barrier types that are typically used in the US
d. Building orientation: influenced exposure to outdoor environmental conditions

We monitored the effect these variables had on temperature, heat flux and moisture accumulation in the cavities of the test walls from October 2011 to November 2012. This report summarizes our results.

\section{Methodology}

\subsection{Building Envelope Systems Testing (BEST) Laboratory}

The BEST lab is a two-story facility, with an approximate $9.1 \mathrm{~m} \times 11 \mathrm{~m}$ footprint, located in the Syracuse University campus in Syracuse, NY (Figure 2). Indoor temperature and relative humidity were set to $20^{\circ} \mathrm{C}$ and $40 \%$, respectively, throughout the test period. This high relative humidity could occur during the winter in buildings with tight envelopes and inadequate mechanical ventilation, and that are located in a cold climate. Throughout the cooling season, indoor air was conditioned with an air source heat pump and a dedicated dehumidifier, while a gas heater and a humidifier were during the heating season. 


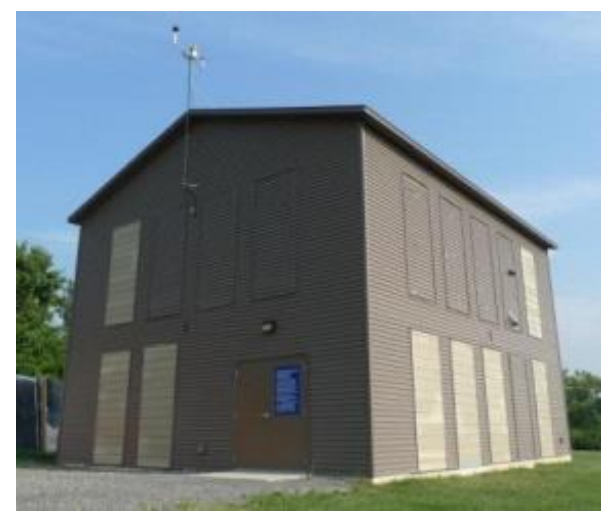

Figure 2. Building Envelope Systems Testing (BEST) lab.

\subsection{Air Barrier Types}

Tables 1 and 2 list the eight air barrier types that are commonly used in residential and commercial construction, and describe the products that were utilized in this project. The manufacturers of the air barrier materials are not identified in order to keep the results nonproduct specific.

Table 1. Air barrier types and materials evaluated in this study.

\begin{tabular}{|c|c|c|}
\hline Air Barrier Type & Description & $\begin{array}{c}\text { Examples of Air Barrier Materials } \\
\text { (underlined materials were evaluated in } \\
\text { this project) }\end{array}$ \\
\hline Interior air barrier & $\begin{array}{l}\text { Membranes and sheathings installed on the inner } \\
\text { side of the stud cavity }\end{array}$ & $\begin{array}{l}\text { - Polyamide membrane } \\
\text { - Polyethylene membrane } \\
\text { - Drywall }\end{array}$ \\
\hline $\begin{array}{l}\text { Mechanically-fastened } \\
\text { membrane }\end{array}$ & $\begin{array}{l}\text { Membranes that are attached to the exterior } \\
\text { sheathing with nails, screws or staples }\end{array}$ & $\begin{array}{l}\text { - Non-woven, spun bonded polyolefin } \\
\text { - Cross-woven polyolefin }\end{array}$ \\
\hline Sealant w/ backup structure & $\begin{array}{l}\text { Exterior sheathings where joints are sealed from the } \\
\text { inner side of the wall }\end{array}$ & $\begin{array}{l}\text { OSB perimeter sealed with caulk or } \\
\text { foam }\end{array}$ \\
\hline Non-insulating sheathing & $\begin{array}{l}\text { Exterior sheathings where joints are sealed from the } \\
\text { exterior side of the building }\end{array}$ & $\begin{array}{l}\text { - } \frac{\text { OSB }}{\text { Plywood }} \\
\text { - Glass matt gypsum board }\end{array}$ \\
\hline Insulating sheathing & $\begin{array}{l}\text { Rigid foam boards that increase the thermal } \\
\text { performance of a wall }\end{array}$ & - XPS rigid foam \\
\hline Self-adhered membrane & $\begin{array}{l}\text { Membranes that are adhered to the exterior } \\
\text { sheathing }\end{array}$ & $\begin{array}{l}\text { - Asphalt-based membrane } \\
\text { - Non-asphalt-based membrane }\end{array}$ \\
\hline Fluid-applied membrane & $\begin{array}{l}\text { Membranes that are brushed, rolled or sprayed to } \\
\text { the exterior sheathing }\end{array}$ & - $\frac{\text { Water-based }}{\text { Solvent-based }}$ \\
\hline Spray-applied foam & $\begin{array}{l}\text { Foams that are sprayed on to the inner or outer side } \\
\text { of exterior sheathings and increase the thermal } \\
\text { performance of a wall }\end{array}$ & $\begin{array}{l}\text { - Open-cell polyurethane foam } \\
\text { - } \text { Closed-cell polyurethane foam }\end{array}$ \\
\hline
\end{tabular}


Table 2. Evaluated air barriers.

\begin{tabular}{|c|c|c|c|}
\hline $\begin{array}{l}\text { Wall } \\
\text { Group }\end{array}$ & Air Barrier Type & Installed Air Barrier & $\begin{array}{l}\text { Location of Air Barrier in } \\
\text { Wall Assembly }\end{array}$ \\
\hline 1 & Spray-applied foam & $7.6 \mathrm{~cm}$ closed-cell foama & Outdoor side of exterior sheathing ${ }^{c}$ \\
\hline 2 & $\begin{array}{l}\text { Mechanically-fastened } \\
\text { membrane }\end{array}$ & Cross-woven polyolefin membrane ${ }^{a}$ & Outdoor side of exterior sheathing ${ }^{c}$ \\
\hline 3 & Insulating sheathing & XPS rigid foam (acted as exterior sheathing)a & Outdoor side of stud cavity \\
\hline 4 & Non-insulating sheathing & OSB with built-in overlaya & Outdoor side of stud cavity \\
\hline 5 & Sealant w/ backup structure & OSB with sealed edges ${ }^{b}$ & Outdoor side of stud cavity \\
\hline 6 & Interior air barrier & $\begin{array}{l}\text { Polyamide membrane that changes its water } \\
\text { vapor permeability with ambient humidityb }\end{array}$ & Indoor side of stud cavity \\
\hline 7 & Fluid-applied membranes & Vapor permeable (>10 perms) ${ }^{a}$ & Outdoor side of exterior sheathing ${ }^{c}$ \\
\hline 8 & Self-adhered membrane & Vapor permeable (>10 perms) ${ }^{\mathrm{a}}$ & Outdoor side of exterior sheathing ${ }^{c}$ \\
\hline
\end{tabular}

\subsection{Test Walls}

Twenty-eight $1.22 \mathrm{~m} \times 2.74 \mathrm{~m}$ wall panels were installed at the BEST lab. Three walls were allocated to each of the eight air barrier types, and Tables 2 and 3 show their assigned group and panel numbers. The remaining four walls were used as controls:

- C1: wood-framed wall without air barrier, but with water-resistive barrier

- C2: 8" concrete masonry unit (CMU) wall without air or water-resistive barrier

- C3: wood-framed wall with polyolefin membrane mechanically-fastened to the indoor side of the stud cavity and to the outdoor side of the exterior sheathing

- C4: steel-framed wall without air barrier, but with water-resistive barrier

Figure 3 illustrates the arrangement of the test specimens in the facility. Wall assemblies were representative of either residential or commercial construction, and the materials used are described in Table 3. Figures 4, 5 and 6 depict the general layout of materials in the panels. All of the walls had $\mathrm{R}_{\mathrm{SI}}$ insulation of $3.7 \mathrm{~K} \cdot \mathrm{m}^{2} / \mathrm{W}\left(\mathrm{R}_{\mathrm{US}}=21 \mathrm{~h} \cdot \mathrm{ft}^{2} \cdot{ }^{\circ} \mathrm{F} / \mathrm{Btu}\right)$ per the IECC. Most of the specimens were built with $2.3 \mathrm{~K} \cdot \mathrm{m}^{2} / \mathrm{W}\left(\mathrm{R}_{\mathrm{US}}=13 \mathrm{~h} \cdot \mathrm{ft}^{2} \cdot{ }^{\circ} \mathrm{F} / \mathrm{Btu}\right) \mathrm{kraft}$-faced fiberglass insulation in the stud cavity, and $1.3 \mathrm{~K} \cdot \mathrm{m}^{2} / \mathrm{W}\left(\mathrm{R}_{\mathrm{US}}=7.5 \mathrm{~h} \cdot \mathrm{ft}^{2} \cdot{ }^{\circ} \mathrm{F} / \mathrm{Btu}\right)$ extruded polystyrene (XPS) boards as exterior continuous insulation. Three of the panels had $7.6 \mathrm{~cm}$ of closed-cell foam applied to the outdoor side of the exterior sheathing as continuous insulation. Four of the panels with interior air barriers (Group 6 and C3) had unfaced fiberglass batts. The edges of the XPS foam were left unsealed in the walls where these boards did not act as the air barrier; however, interior joints were ship lapped to prevent water intrusion. Interior drywall was left unpainted and its edges unsealed to minimize its role as a vapor retarder and an air barrier. Additionally, the drywall included an electrical outlet that was used to feed sensor wires into the walls and as an air leakage pathway. 
First Floor

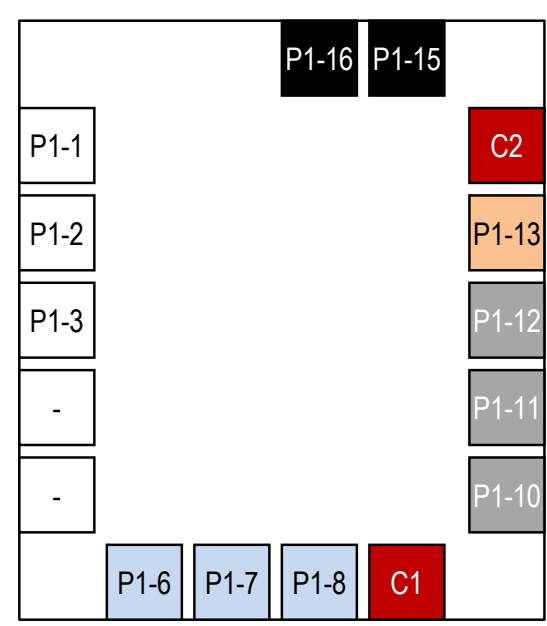

Second Floor

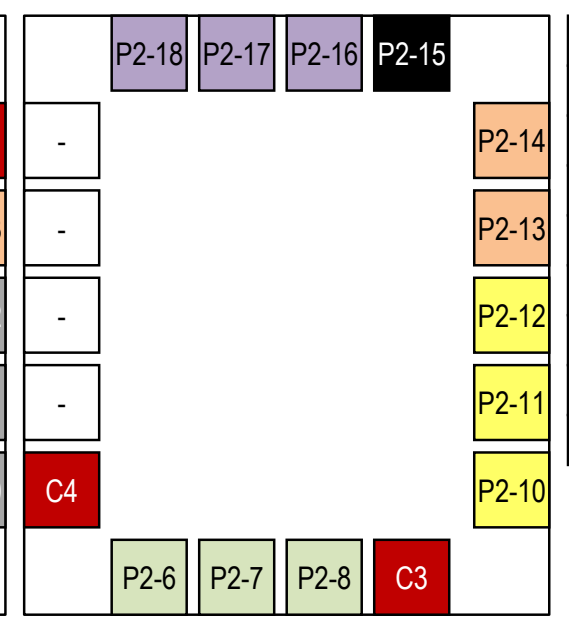

Group 1: spray-applied foam

Group 2: mechanically-fastened membrane

Group 3: insulating sheathing

Group 4: non-insulating sheathing

Group 5: sealant w/ backup structure

Group 6: interior air barrier

Group 7: fluid-applied membrane

Group 8: self-adhered membrane

Controls

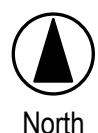

Figure 3. Panel and air barrier type layout at the BEST lab.

All the panels that were part of a group were tightly built as their initial leakage rates typically did not exceed $\sim 0.05 \mathrm{~L} /\left(\mathrm{s} \cdot \mathrm{m}^{2}\right)$ at a pressure differential $(\Delta \mathrm{P})$ of $75 \mathrm{~Pa}$. Afterwards, holes were added to two of the panels in each of the groups in order to introduce variations in air leakage. The targeted rates were: Level $1 \cong 0.02 \mathrm{~L} /\left(\mathrm{s} \cdot \mathrm{m}^{2}\right)$, Level $2 \cong 0.2 \mathrm{~L} /\left(\mathrm{s} \cdot \mathrm{m}^{2}\right)$, and Level $3 \cong 1$ $\mathrm{L} /\left(\mathrm{s} \cdot \mathrm{m}^{2}\right)$ at $75 \mathrm{~Pa}$; although these airflows were not precisely attained because this was not a major objective. Holes in the Level 2 and Level 3 walls were laid out to simulate typical construction imperfections that lead to air leakage as illustrated in Figure 7. 
Table 3. Materials installed in wall panels.

\begin{tabular}{|c|c|c|c|c|c|c|}
\hline $\begin{array}{l}\text { Wall } \\
\text { Group }\end{array}$ & $\begin{array}{c}\text { Wall } \\
\text { Panels }\end{array}$ & Siding & $\begin{array}{c}\text { Exterior } \\
\text { Insulation } \\
\left(\mathrm{K} \cdot \mathrm{m}^{2} / \mathrm{W}\right) \\
\end{array}$ & $\begin{array}{l}\text { Exterior } \\
\text { Sheathing }\end{array}$ & Framing & $\begin{array}{c}\text { Cavity } \\
\text { Insulation } \\
\left(\mathrm{K} \cdot \mathrm{m}^{2} / \mathrm{W}\right) \\
\end{array}$ \\
\hline 1 & P1-1, P1-2, P1-3 & Fiber cement & $\begin{array}{c}7.6 \mathrm{~cm} \text { cc foam } \\
(3.7)\end{array}$ & GMG & $8.9 \mathrm{~cm}$ steel & - \\
\hline 2 & P1-6, P1-7, P1-8 & Fiber cement & $3.8 \mathrm{~cm}$ XPS (1.3) & GMG & $8.9 \mathrm{~cm}$ steel & FFG (2.3) \\
\hline 3 & $\mathrm{P} 1-10, \mathrm{P} 1-11, \mathrm{P} 1-12$ & Fiber cement & $3.8 \mathrm{~cm}$ XPS (1.3) & - & $8.9 \mathrm{~cm}$ steel & FFG (2.3) \\
\hline 4 & P2-6, P2-7, P2-8 & Vinyl & $3.8 \mathrm{~cm}$ XPS (1.3) & OSB & $\begin{array}{c}3.8 \times 8.9 \mathrm{~cm} \\
\text { wood }\end{array}$ & FFG (2.3) \\
\hline 5 & P2-10, P2-11, P2-12 & Vinyl & $3.8 \mathrm{~cm}$ XPS (1.3) & OSB & $\begin{array}{c}3.8 \times 8.9 \mathrm{~cm} \\
\text { wood }\end{array}$ & FFG (2.3) \\
\hline 6 & P2-16, P2-17, P2-18 & Vinyl & $3.8 \mathrm{~cm}$ XPS (1.3) & OSB & $\begin{array}{c}3.8 \times 8.9 \mathrm{~cm} \\
\text { wood }\end{array}$ & UFG (2.3) \\
\hline 7 & $\mathrm{P} 1-13, \mathrm{P} 2-13, \mathrm{P} 2-14$ & Fiber cement & $3.8 \mathrm{~cm}$ XPS (1.3) & GMG & $8.9 \mathrm{~cm}$ steel & FFG (2.3) \\
\hline 8 & $P 1-15, P 1-5, P 2-15$ & Fiber cement & $3.8 \mathrm{~cm}$ XPS (1.3) & GMG & $8.9 \mathrm{~cm}$ steel & FFG (2.3) \\
\hline- & $\mathrm{C} 1$ & Vinyl & $3.8 \mathrm{~cm}$ XPS (1.3) & OSB & $\begin{array}{c}3.8 \times 8.9 \mathrm{~cm} \\
\text { wood }\end{array}$ & FFG (2.3) \\
\hline- & $\mathrm{C} 2$ & - & - & - & $20.3 \mathrm{~cm} \mathrm{CMU}$ & - \\
\hline- & C3 & Vinyl & $3.8 \mathrm{~cm}$ XPS (1.3) & OSB & $\begin{array}{c}3.8 \times 8.9 \mathrm{~cm} \\
\text { wood }\end{array}$ & UFG (2.3) \\
\hline- & $\mathrm{C} 4$ & Fiber cement & $3.8 \mathrm{~cm}$ XPS (1.3) & GMG & $8.9 \mathrm{~cm}$ steel & FFG (2.3) \\
\hline
\end{tabular}

Abbreviations: cc, closed-cell; C, control; FFG, kraft-faced fiberglass insulation batts; UFG, unfaced fiberglass insulation batts;

GMG, glass mat gypsum; OSB, oriented strand board; P, panel label per Figure 3; XPS, extruded polystyrene insulation board.

a. $\quad$ All panels had unsealed and unpainted drywall on their interior except $\mathrm{C} 2$.

b. Half inch rain screen was installed between siding and exterior insulation.

c. Steel studs had holes or knockouts in their webs.

d. Interior and exterior edges of XPS insulation boards were left unsealed except in the Group 3 walls. Interior joints were ship lapped to prevent water intrusion. 


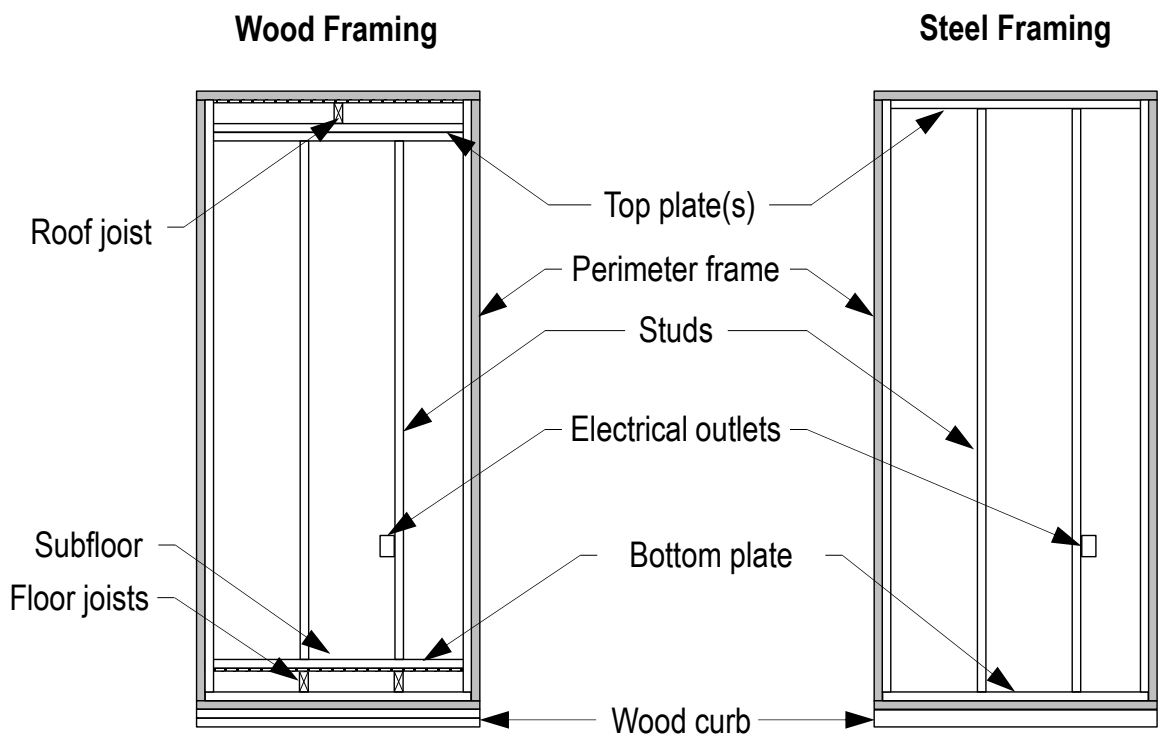

Figure 4. Wall elevations.

\subsection{Sensors}

Table 4 lists the utilized sensors. Data from all sensors, except from pressure transducers, were scanned every minute and are reported as hourly averages. Pressure measurements were collected every 30 seconds and are reported as hourly averages. Temperature and relative humidity measurements that were gathered at the same location were utilized to estimate water vapor pressures and humidity ratios based on equations from the 2009 ASHRAE Fundamentals Handbook (ASHRAE 2009). Data measured when Syracuse University pressurized the building to conduct air leakage tests were not used as part of the analysis.

Table 4. Sensor description.

\begin{tabular}{|c|c|c|c|c|c|}
\hline Parameter & Manufacturer & Sensor Model & Accuracy & Sensitivity & Repeatability \\
\hline \multicolumn{6}{|l|}{ Wall panels and indoors } \\
\hline Temperature & Honeywell/Fenwal & 192-103LET-A01 & $\pm 0.2 \%$ & . & $\pm 0.2 \%$ \\
\hline Relative humidity & Honeywell & $\mathrm{HIH}-4000$ & $\pm 3.5 \%$ & - & $\pm 0.5 \%$ \\
\hline Heat flux & Concept Engineering & F-002-4 & $\pm 5 \%$ & $5.7\left(\mathrm{~W} / \mathrm{m}^{2}\right) / \mathrm{mV}$ & - \\
\hline Pressure & Energy Conservatory & APT & $\begin{array}{c}>\text { of } \pm 1 \% \text { or } \\
0.2 \mathrm{~Pa}\end{array}$ & $0.1 \mathrm{~Pa}$ & - \\
\hline \multicolumn{6}{|l|}{ Weather station } \\
\hline Temperature & Campbell Scientific & CS215 & $\pm 0.9^{\circ} \mathrm{C}$ & - & - \\
\hline Relative humidity & Campbell Scientific & CS215 & $\pm 2 \%$ & - & - \\
\hline Wind speed/direction & Gill & WindSonic & $\begin{array}{c} \pm 2 \% \text { speed } \\
\pm 3 \% \text { direction }\end{array}$ & $\begin{array}{c}0.01 \mathrm{~m} / \mathrm{s} \text { speed } \\
1^{\circ} \text { direction }\end{array}$ & - \\
\hline Rainfall & Texas Electronics & TE525WS & $\pm 1 \%$ & - & - \\
\hline Total solar radiation & Hukseflux & LP02 & $< \pm 1 \%$ & $15 \mu \mathrm{V} /\left(\mathrm{W} / \mathrm{m}^{2}\right)$ & - \\
\hline Solar radiation on vertical surfaces & Campbell Scientific & LI200X & $\pm 3 \%$ & $0.2\left(\mathrm{~kW} / \mathrm{m}^{2}\right) / \mathrm{mV}$ & - \\
\hline Atmospheric pressure & Vaisala & CS106 & $\pm 100 \mathrm{~Pa}$ & - & $\pm 3 \mathrm{~Pa}$ \\
\hline
\end{tabular}

Figure 8 illustrates the general layout of the temperature $(\mathrm{T})$, relative humidity $(\mathrm{RH})$, heat flux $(\mathrm{HF})$, pressure (P), and moisture pins (MP) sensors in the panels. The location of these instruments varied somewhat depending on the air barrier type and the placement of the air barrier in the wall assembly. 

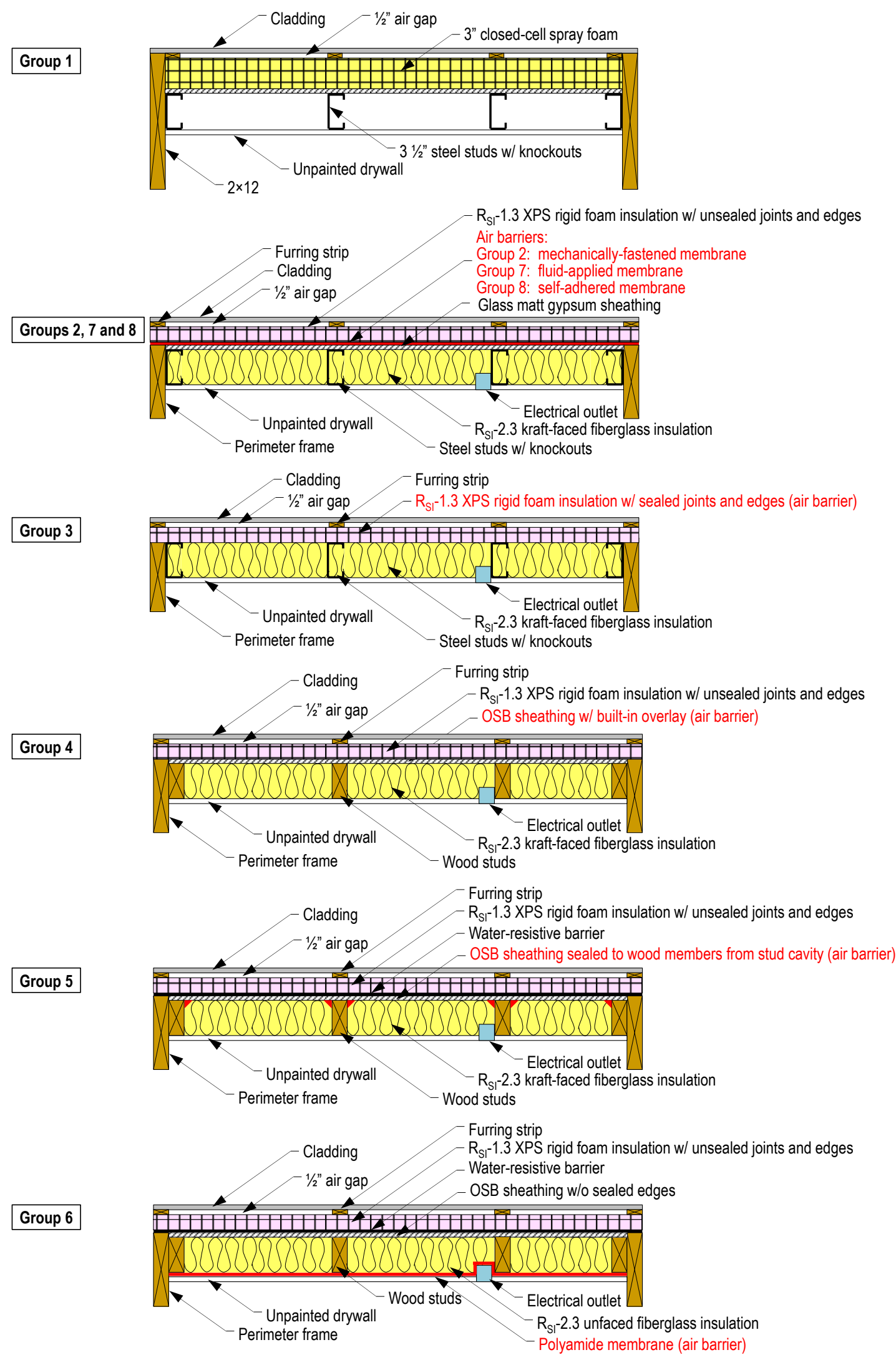

Figure 5. Material layout in test walls. 

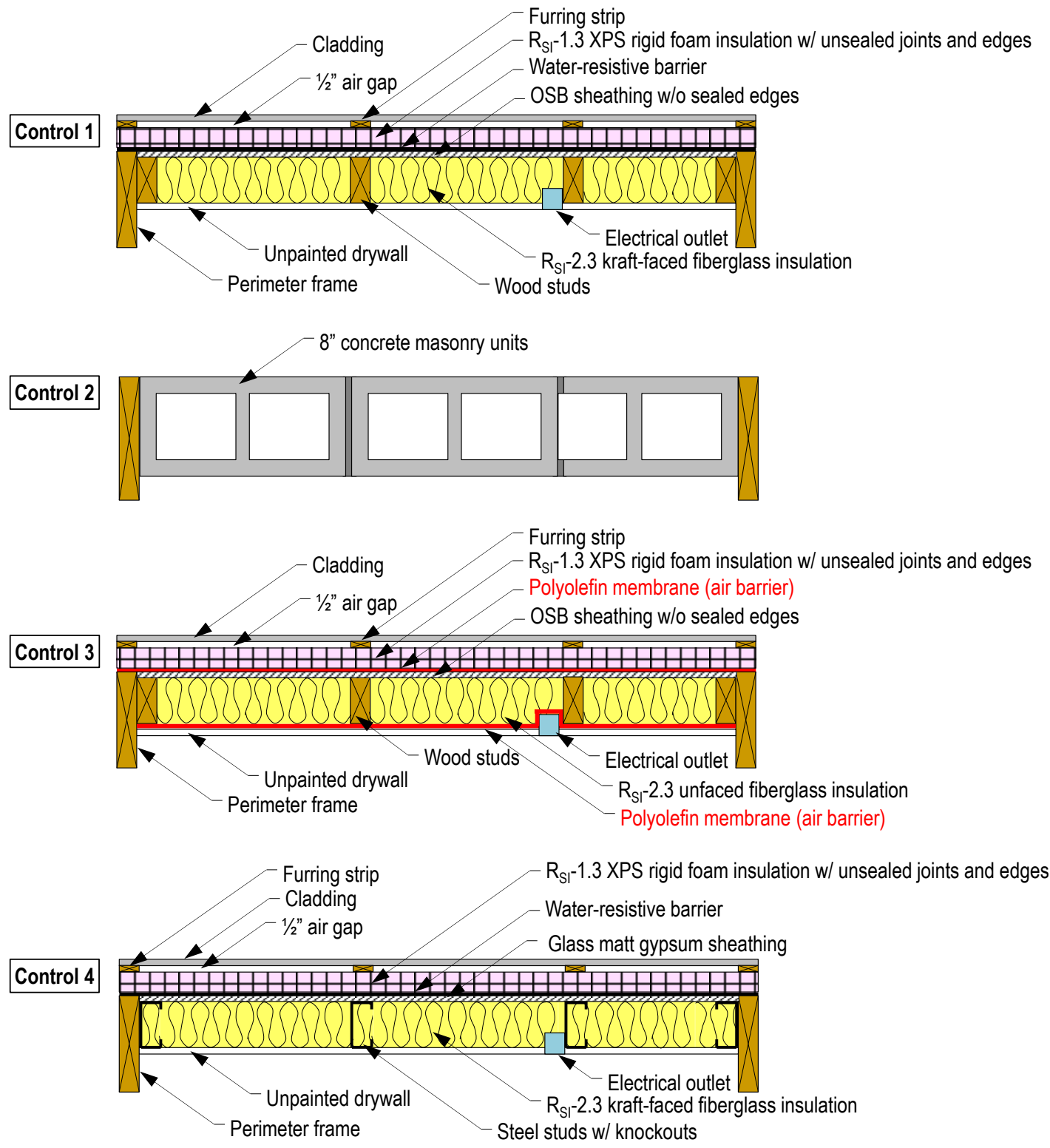

Figure 6. Material layout in control walls. 


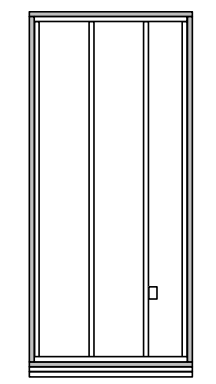

$\mathrm{P} 1-3<0.02 \mathrm{~L} / \mathrm{s} \cdot \mathrm{m}^{2}$
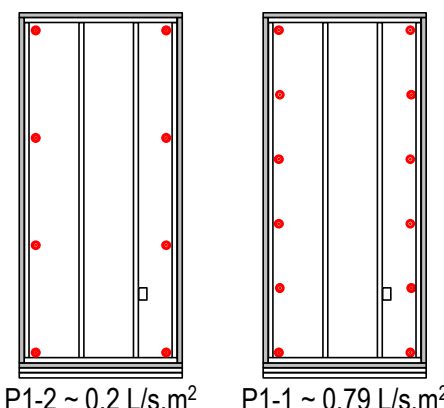

Group 1: spray-applied foam. Hole layout simulated spray foam detachment from structure due to improper application.
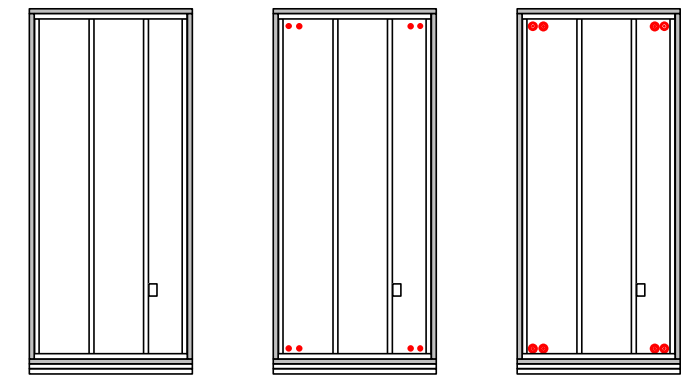

$\mathrm{P} 1-10 \sim 0.03 \mathrm{~L} / \mathrm{s} \cdot \mathrm{m}^{2} \quad \mathrm{P} 1-11 \sim 0.36 \mathrm{~L} / \mathrm{s} \cdot \mathrm{m}^{2} \quad \mathrm{P} 1-12 \sim 0.5 \mathrm{~L} / \mathrm{s} \cdot \mathrm{m}^{2}$ Group 3: insulating sheathing. Hole layout simulated unsealed but joints between insulating sheaths.
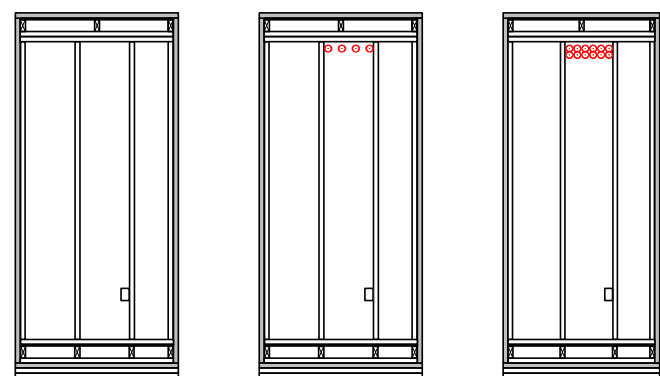

$\mathrm{P} 2-12 \sim 0.09 \mathrm{~L} / \mathrm{s} \cdot \mathrm{m}^{2} \quad \mathrm{P} 2-11 \sim 0.19 \mathrm{~L} / \mathrm{s} \cdot \mathrm{m}^{2} \quad \mathrm{P} 2-10 \sim 0.52 \mathrm{~L} / \mathrm{s} \cdot \mathrm{m}^{2}$ Group 5: sealant w/ backup structure. Hole layout simulated an unsealed OSB joint at top plate.
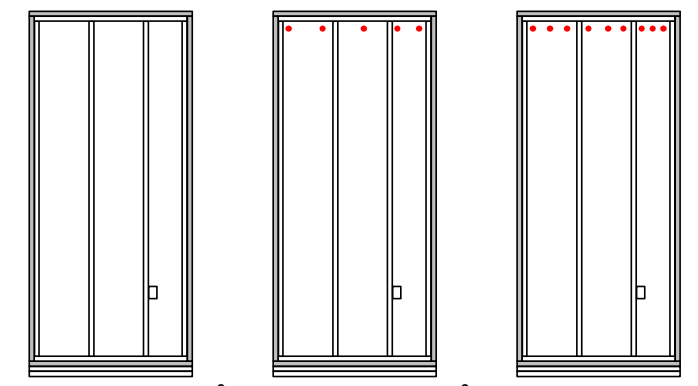

$\mathrm{P} 2-13<0.02 \mathrm{~L} / \mathrm{s} \cdot \mathrm{m}^{2} \quad \mathrm{P} 2-14 \sim 0.17 \mathrm{~L} / \mathrm{s} \cdot \mathrm{m}^{2} \quad \mathrm{P} 1-13 \sim 0.74 \mathrm{~L} / \mathrm{s} \cdot \mathrm{m}^{2}$

Group 7: fluid-applied membrane. Hole layout simulated an unsealed exterior drywall sheathing joint at the top track.
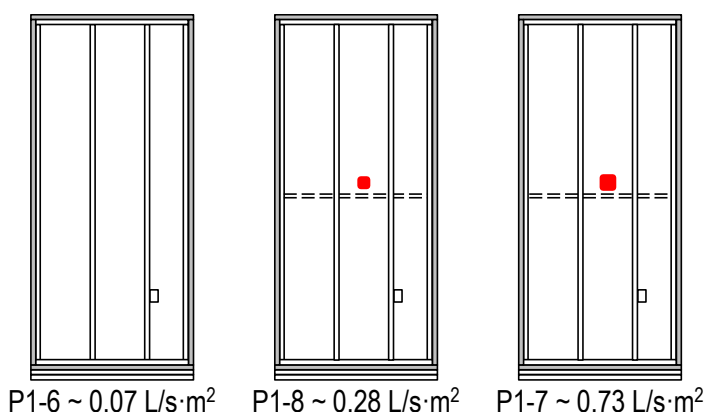

Group 2: mech-fastened membrane. Holes simulated a penetration through the air barrier. Spacer placed between air barrier and XPS.
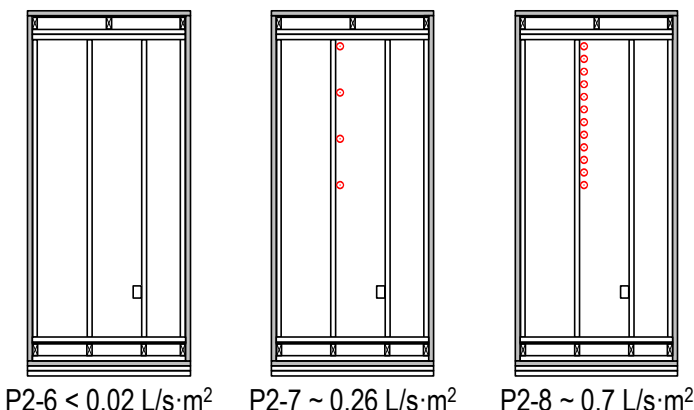

$\mathrm{P} 2-6<0.02 \mathrm{~L} / \mathrm{s} \cdot \mathrm{m}^{2}$

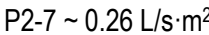

$\mathrm{P} 2-8 \sim 0.7 \mathrm{~L} / \mathrm{s} \cdot \mathrm{m}^{2}$ Group 4: non-insulating sheathing. Hole layout simulated an unsealed OSB joint at stud.
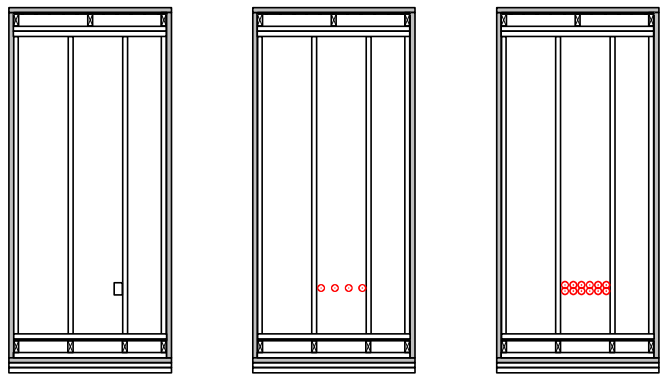

$\mathrm{P} 2-16 \sim 0.08 \mathrm{~L} / \mathrm{s} \cdot \mathrm{m}^{2} \quad \mathrm{P} 2-17 \sim 0.2 \mathrm{~L} / \mathrm{s} \cdot \mathrm{m}^{2} \quad \mathrm{P} 2-18 \sim 0.55 \mathrm{~L} / \mathrm{s} \cdot \mathrm{m}^{2}$ Group 6: interior air barrier. Hole layout simulated a penetration through the air barrier.
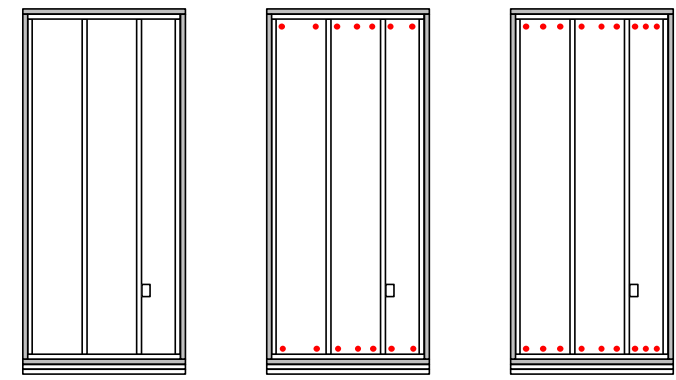

$\mathrm{P} 2-15<0.02 \mathrm{~L} / \mathrm{s} \cdot \mathrm{m}^{2} \quad \mathrm{P} 1-16 \sim 0.19 \mathrm{~L} / \mathrm{s} \cdot \mathrm{m}^{2} \quad \mathrm{P} 1-15 \sim 1.03 \mathrm{~L} / \mathrm{s} \cdot \mathrm{m}^{2}$

Group 8: self-adhered membrane. Hole layout simulated an unsealed exterior drywall sheathing joint at the top/bottom tracks.

Figure 7. Panel groups with added imperfections and 12-month average air leakage rates at $75 \mathrm{~Pa}$. 
Vertical Cross Section

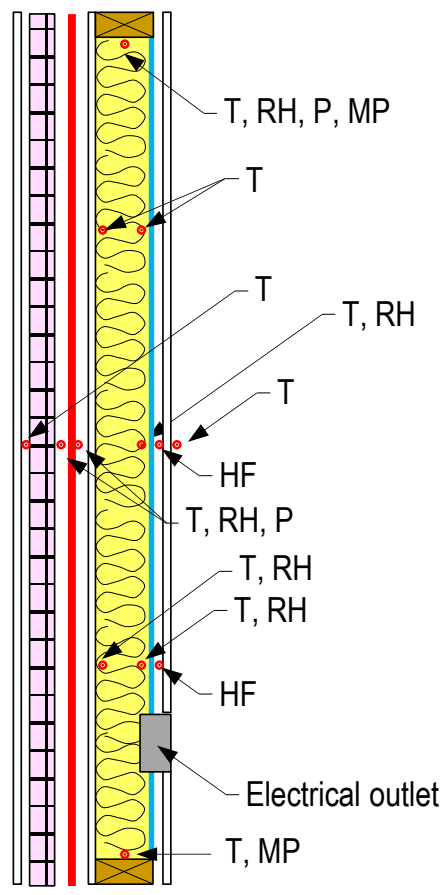

\author{
General material layout \\ Siding \\ $1 / 2$ " Rain screen \\ $11 / 2 " X P S$ rigid foam \\ Air barrier \\ Exterior sheathing \\ Fiberglass batts \\ Fiberglass facing or interior air barrier \\ Unpainted drywall
}

\author{
Sensors \\ HF: heat flux \\ MP: moisture pin \\ $\mathrm{P}$ : pressure \\ $\mathrm{RH}$ : relative humidity \\ $\mathrm{T}$ : temperature
}

Figure 8. General sensor layout within the center-stud cavity of test walls.

\title{
2.5 Energy monitoring
}

Heat flux measurements were used to examine the effects of air leakage on energy loads. Two sensors were installed in each wall between the facing of the fiberglass insulation and the interior drywall (Figure 8). One sensor was located in the middle of the panel to represent the average flux through the wall. The second sensor was close to the electrical outlet opening through the interior drywall to increase its exposure to airflows in the wall cavity, and measure the potential maximum fluxes. To isolate the effects from air leakage, heat fluxes from the Level 2 and Level 3 walls were compared against those from the Level 1 panel, where measurements were mostly due to conduction because of its airtight construction (i.e., $\sim 0.02 \mathrm{~L} /\left(\mathrm{s} \cdot \mathrm{m}^{2}\right)$ at $75 \mathrm{~Pa}$ ). Although not perfect, this technique was selected as an intermediate method to estimate the contribution from air leakage to energy loads because the other two typically used alternatives had their own limitations. The ideal setup to quantify the effects of airflow would have been similar to that of a hot box; however, this is a cost-prohibitive approach. The conventional method to estimate the effects of air leakage is to use the product of the airflow rate times the enthalpy difference between indoors and outdoors; however, this method does not take into account heat exchanges between the infiltrating/exfiltrating air and the wall cavity materials that are in the airflow path (Sherman and Walker 2001). 


\subsection{Characterization of the air leakage of the test walls}

Syracuse University characterized the air leakage of each of the panels every two months from September 2011 until July 2012 using a procedure similar to the blower door fan pressurization technique. An airtight portable box that sealed against the perimeter of a test wall was built to create a pressure differential across the specimen (Figure 9). The pressurizing box was connected to a variable speed blower that regulated the $\Delta \mathrm{P}$ across the wall, and a TSI flow meter (minimum flow rate $=4 \mathrm{~L} / \mathrm{min}$ ) measured the airflow rate required to generate pressure differentials of 25,50 and $75 \mathrm{~Pa}$. A second blower was used to pressurize the building and maintain a zero $\Delta \mathrm{P}$ across the portable box, which ensured that airflow measurements were due to leakage through the test panel and not through the box.

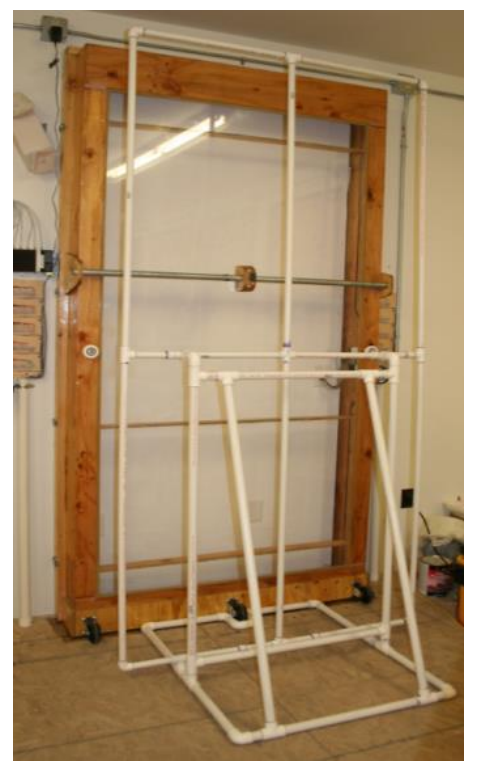

Figure 9. Test wall pressurization setup.

\section{Results and Discussion}

\subsection{Wall Panel Air Leakage Characterization}

The bi-monthly airflow rates at $\Delta \mathrm{P}=75 \mathrm{~Pa}\left(\mathrm{Q}_{75}\right)$ are illustrated in Figure 10 and their averages are listed in Table 5. Measurements recorded as $<0.02 \mathrm{~L} /\left(\mathrm{s} \cdot \mathrm{m}^{2}\right)$ denote that the airflow rate was lower than the flow meter limit. Specimens that leaked because of drilled holes showed minimal variation; their maximum standard deviation $(\mathrm{SD})$ was $0.08 \mathrm{~L} /\left(\mathrm{s} \cdot \mathrm{m}^{2}\right)$. In contrast, $\mathrm{Q}_{75}$ flows from the Control 1 (C1), which lacked an air barrier, had a larger SD of $0.2 \mathrm{~L} /\left(\mathrm{s} \cdot \mathrm{m}^{2}\right)$. Control $3(\mathrm{C} 3)$ also did not have an air barrier and its initial $\mathrm{Q}_{75}$ rate was $0.86 \mathrm{~L} /\left(\mathrm{s} \cdot \mathrm{m}^{2}\right)$. However, this value decreased to about $0.17 \mathrm{~L} /\left(\mathrm{s} \cdot \mathrm{m}^{2}\right)$ after the first measurement possibly because the XPS insulation sealed against the exterior sheathing and improved the airtightness of the panel. Control 2 (CMU wall) is not included in Table 5 because its air leakage exceeded the flow meter capacity $(300 \mathrm{~L} / \mathrm{s}$ or $\left.1.5 \mathrm{~L} /\left(\mathrm{s} \cdot \mathrm{m}^{2}\right)\right)$. This panel had to be covered with a polyethylene sheet throughout the study because its high leakage significantly affected the air exchange rate of the test facility and prevented pressurizing the building to characterize the airtightness of the other walls. 

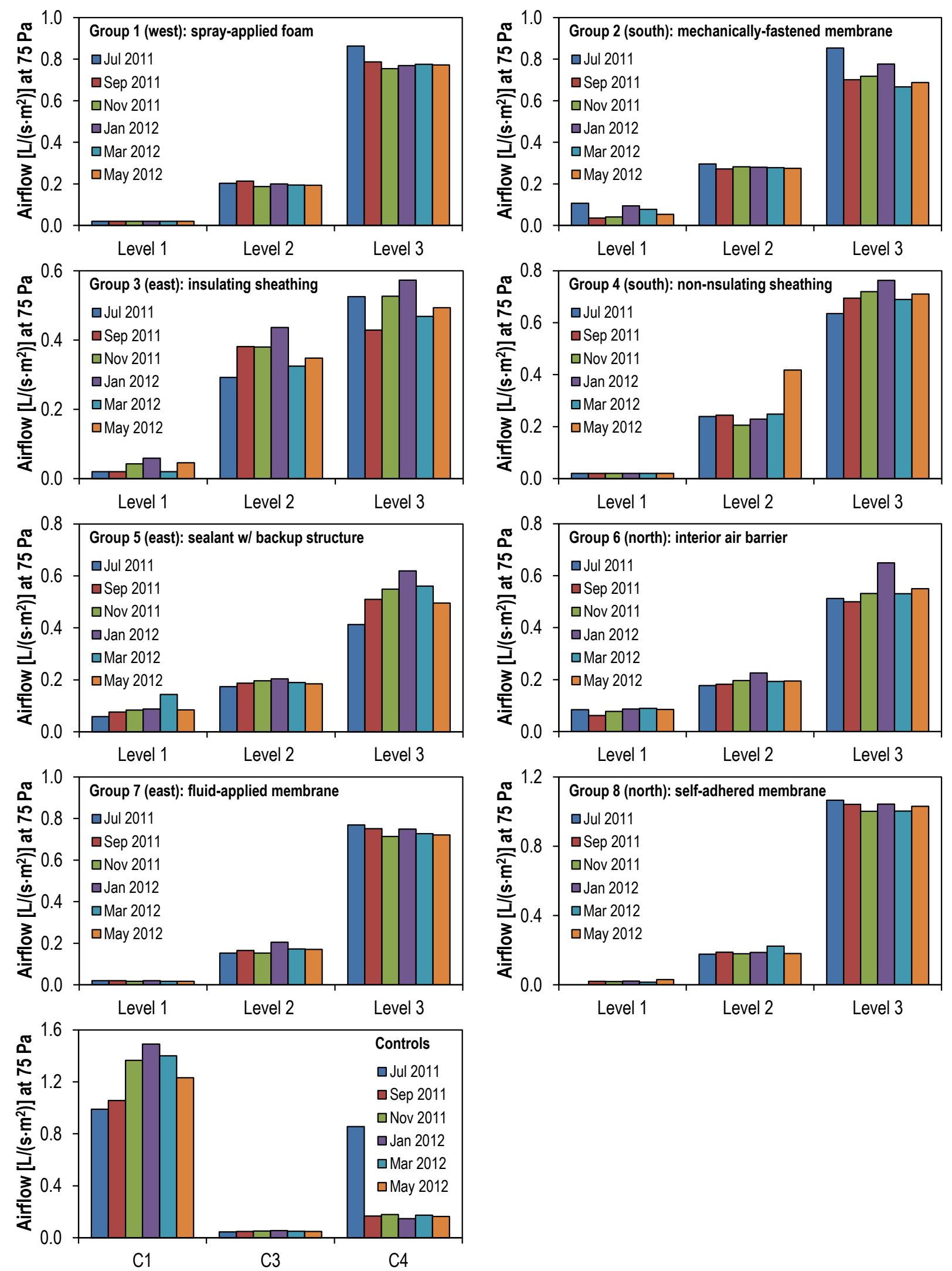

Figure 10. Bi-monthly air leakage measurements at $75 \mathrm{~Pa}$. 
Table 5. Air leakage rates $\left[\mathrm{L} /\left(\mathrm{s} \cdot \mathrm{m}^{2}\right)\right]$ of wall panels at $75 \mathrm{~Pa}$.

\begin{tabular}{|c|c|c|c|c|c|c|c|c|}
\hline Panel & Average & SD & Panel & Average & SD & Panel & Average & SD \\
\hline Group 1 & & & Group 4 & & & Group 7 & & \\
\hline P1-3 & $<0.02$ & - & P2-6 & $<0.02$ & - & P2-13 & $<0.02$ & - \\
\hline P1-2 & 0.2 & 0.01 & P2-7 & 0.26 & 0.08 & P2-14 & 0.17 & 0.02 \\
\hline P1-1 & 0.79 & 0.04 & P2-8 & 0.7 & 0.04 & P1-13 & 0.74 & 0.02 \\
\hline Group 2 & & & Group 5 & & & Group 8 & & \\
\hline P1-6 & 0.07 & 0.03 & P2-12 & 0.09 & 0.03 & P2-15 & $<0.02$ & - \\
\hline P1-8 & 0.28 & 0.01 & P2-11 & 0.19 & 0.01 & P1-16 & 0.19 & 0.02 \\
\hline P1-7 & 0.73 & 0.07 & $\mathrm{P} 2-10$ & 0.52 & 0.07 & P1-15 & 1.03 & 0.03 \\
\hline Group 3 & & & Group 6 & & & Controls & & \\
\hline P1-10 & 0.03 & 0.02 & P2-16 & 0.08 & 0.01 & C1 & 1.26 & 0.2 \\
\hline P1-11 & 0.36 & 0.05 & P2-17 & 0.2 & 0.02 & C3 & $0.17^{a}$ & $0.01^{a}$ \\
\hline P1-12 & 0.5 & 0.05 & P2-18 & 0.55 & 0.05 & C4 & 0.05 & 0 \\
\hline
\end{tabular}

a. The July measurement was not used in the calculations because Figure 10 indicates that the materials in the panel likely moved after this date and this made the wall more airtight.

\subsection{Environmental Conditions}

Monthly average indoor and outdoor temperature, relative humidity, humidity ratio and water vapor pressures are described in Figure 11. Indoor temperature was maintained relatively constant at about $21^{\circ} \mathrm{C}$, while indoor relative humidity was more difficult to control: monthly averages ranged from 32 to $46 \%$. Outdoor temperature were the lowest in January (average $=$ $-1.6^{\circ} \mathrm{C}$ ) and increased to $23.9^{\circ} \mathrm{C}$ in July. Monthly average outdoor relative humidity remained between 60\% (April) and 77\% (October) throughout the year. Indoor relative humidity tracked the humidity ratio given that indoor temperature was fairly constant. In contrast, outdoor humidity ratio followed the same pattern as the outdoor temperature: lowest measurements in the winter and highest values in the summer. Water vapor pressures indicate that, on average, indoor sources of moisture were dominant from November 2011 until April 2012, with maximum average indoor-to-outdoor vapor pressure differentials of about $0.5 \mathrm{kPa}$ in January and February. Outdoor sources prevailed during the remaining months of the year, with maximum average outdoor-to-indoor vapor pressure differentials of approximately $0.7 \mathrm{kPa}$ in July and August. 

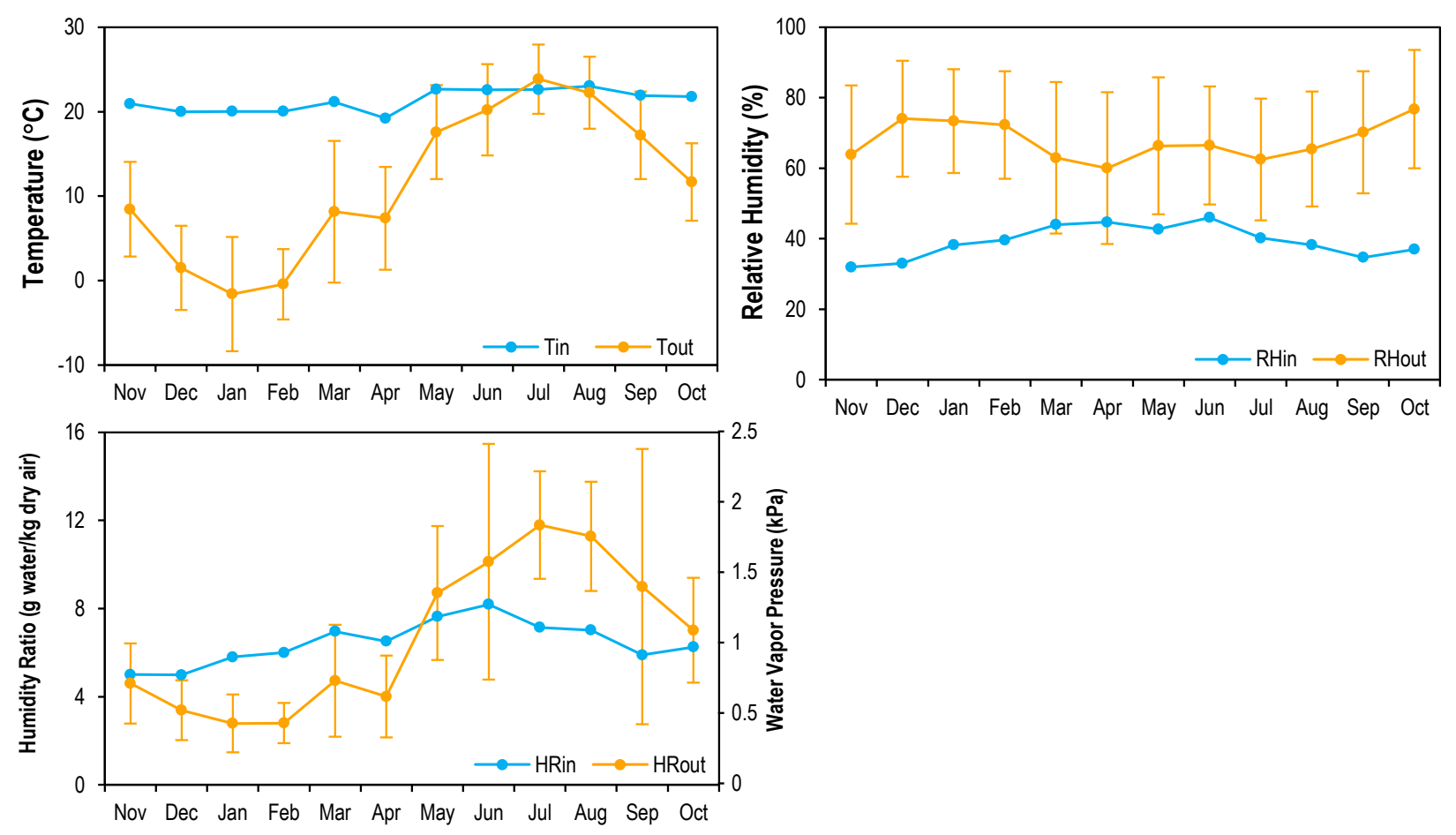

Figure 11. Monthly average indoor and outdoor conditions.

a. Whiskers denote standard deviations.

Figure 12 shows the monthly average and distribution of the wind speeds. South and west winds were dominant, especially during the winter months, while east winds were typically the weakest throughout the entire year. Monthly average outdoor-to-indoor pressure differentials for the four building sides and their distributions are described in Figure 13. These differentials were mostly obtained through pressure transducers, but some values were estimated using the measured wind speeds and the procedure reported by Swami and Chandra (1987) when sensors failed. Monthly average pressure differential values from all building sides spanned from -3.7 to $5.1 \mathrm{~Pa}$;

however, their distribution covered a large range. For example, the south side of the facility experienced pressure values that spanned from $-17 \mathrm{~Pa}\left(5^{\text {th }}\right.$ percentile $)$ to $21 \mathrm{~Pa}\left(95^{\text {th }}\right.$ percentile). Additionally, Figure 13 shows that the south and west facing panels experienced both positive (i.e., $\mathrm{P}_{\text {out }}>\mathrm{P}_{\text {in }}$ ) and negative (i.e., $\mathrm{P}_{\text {out }}<\mathrm{P}_{\text {in }}$ ) pressure differentials. In contrast, the east and north facing panels were subjected primarily to negative pressure differentials that led to exfiltration. 

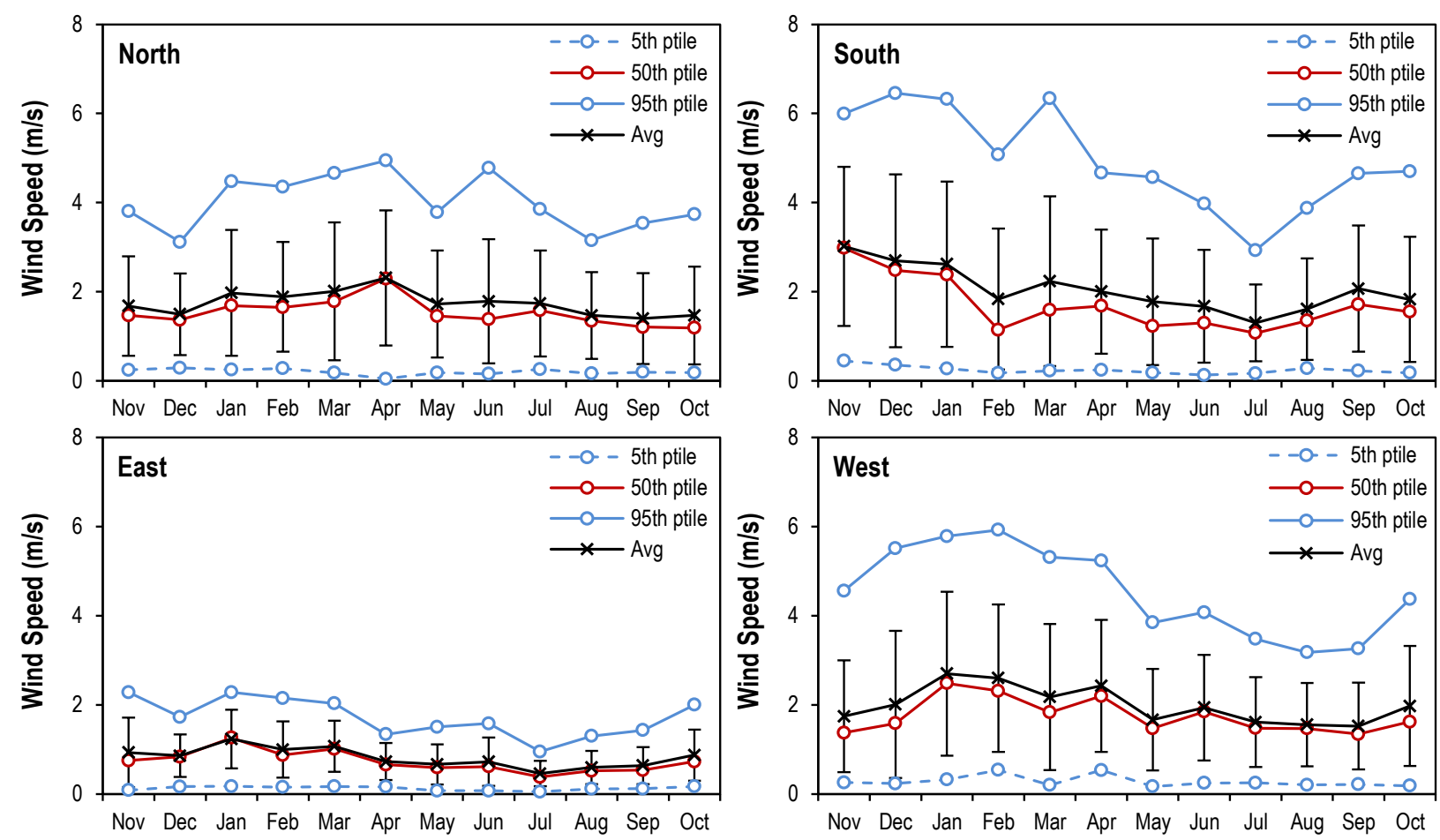

Figure 12. Monthly average wind speeds measured at the weather station located in the grounds of the test facility.

a. Whiskers denote standard deviations.
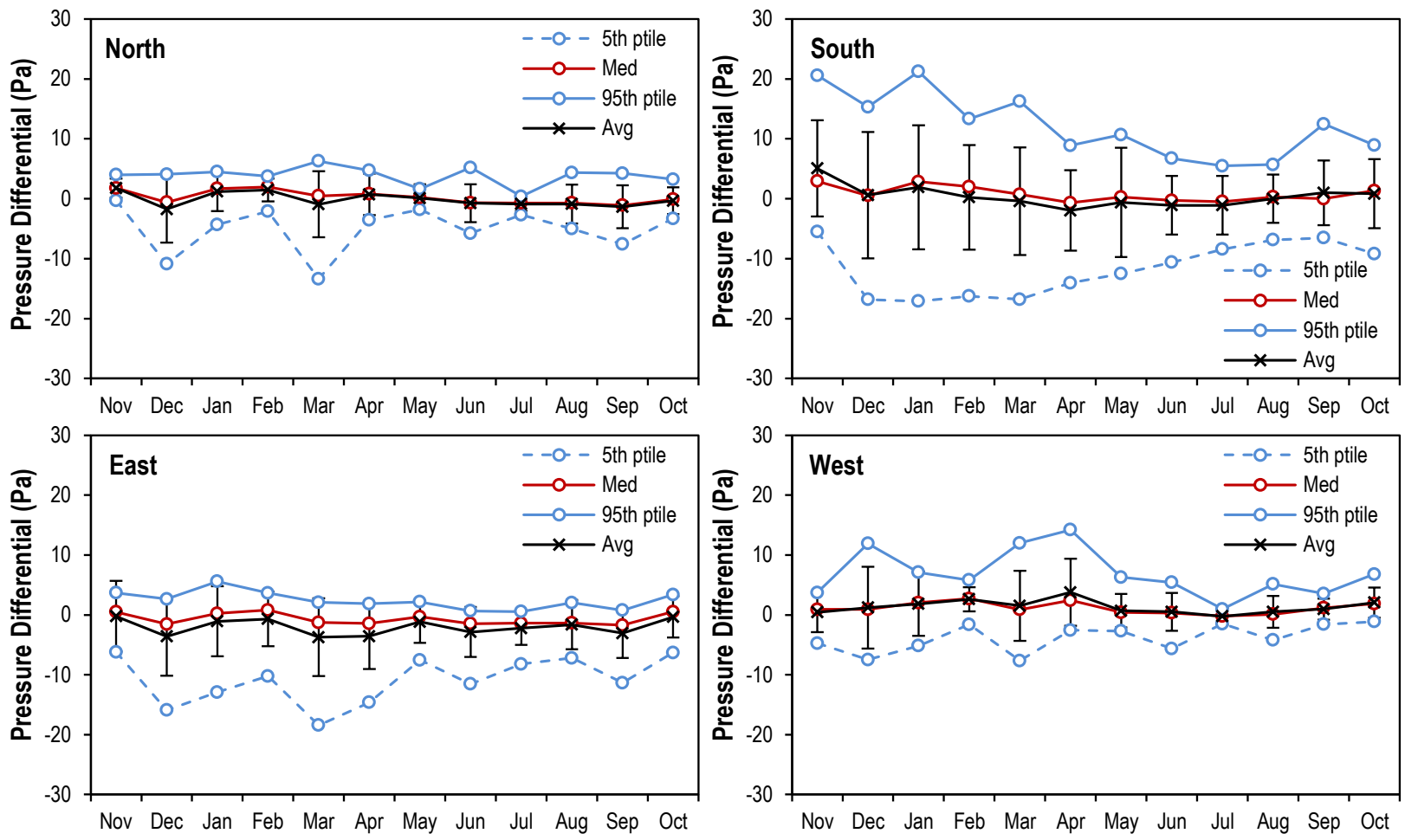

Figure 13. Monthly average outdoor-to-indoor building pressure differentials.

a. Whiskers denote standard deviations.

b. Positive pressure differentials indicate that outdoor pressure was higher than indoor pressure. 


\subsection{Energy Loads}

A survey of the data suggested that the south-facing Group 4 panels best illustrated the effect of air leakage on energy loads. These walls were selected primarily because south winds were typically dominant, and most of the sensors were within the main airflow path. Therefore, the energy-related findings that follow focus on this group of walls, and concentrate on the heating season because indoor-to-outdoor temperature differentials were the highest during this time of the year.

Heat fluxes varied with indoor-to-outdoor temperature $\left(\mathrm{T}_{\text {in }}-\mathrm{T}_{\text {out }}\right)$ differentials and outdoor-toindoor pressure differentials $\left(\mathrm{P}_{\text {out }}-\mathrm{P}_{\text {in }}\right)$. Figure 14 shows the monthly heat fluxes that were collected while windward pressure occurred on the south side of the building (i.e., $\mathrm{P}_{\text {out }}>\mathrm{P}_{\text {in }}$ ). Differences between the fluxes at $1 / 4$ height $\left(\mathrm{HF}_{1 / 4}\right)$ and $1 / 2$ height $\left(\mathrm{HF}_{1 / 2}\right)$ were minimal in the Level 1 and Level 2 walls because of their relatively low air leakage rates. In contrast, $\mathrm{HF}_{1 / 4}$ measurements were typically about $25 \%$ higher than $\mathrm{HF}_{1 / 2}$ values in the Level 3 panel, given that the former was more exposed to airflows due to its close proximity to the electrical outlet opening. Maximum heat fluxes occurred in January 2012 when the average $\mathrm{T}_{\text {in }}-\mathrm{T}_{\text {out }}$ was $21.6^{\circ} \mathrm{C}$ and $\mathrm{P}_{\text {out }}-\mathrm{P}_{\text {in }}$ measurements were: monthly average $=1.9 \mathrm{~Pa}, 5^{\text {th }}$ percentile $=-17 \mathrm{~Pa}, 95^{\text {th }}$ percentile $=21 \mathrm{~Pa}$. During this month, $\mathrm{HF}_{1 / 2}$ values from the Level 1, Level 2 and Level 3 panels were 900,980 , and $1330 \mathrm{~W} \cdot \mathrm{h} / \mathrm{m}^{2}$, respectively. The corresponding $\mathrm{HF}_{1 / 4}$ measurements were 920,1030 , and $1740 \mathrm{~W} \cdot \mathrm{h} / \mathrm{m}^{2}$.

Table 6 summarizes the percent increase in heat flux due to infiltration. Results suggest that air leakage through the Level 3 panel $\left(\mathrm{Q}_{75}=0.7 \mathrm{~L} /\left(\mathrm{s} \cdot \mathrm{m}^{2}\right)\right)$ led to monthly heat fluxes that were $37 \%$ to $97 \%$ higher than those measured in the Level 1 wall. These percent differences were influenced by the relatively high insulation in the walls; that is, if a lower R-value had been used, then the relative contribution from airflow to heat flux would have been less. Moreover, Table 6 shows that decreasing $\mathrm{Q}_{75}$ from 0.26 to $0.02 \mathrm{~L} /\left(\mathrm{s} \cdot \mathrm{m}^{2}\right)$ led to monthly reductions in heat flux that ranged from 5 to $13 \%$. These results give insight of when additional efforts to improve airtightness may become less cost-effective.

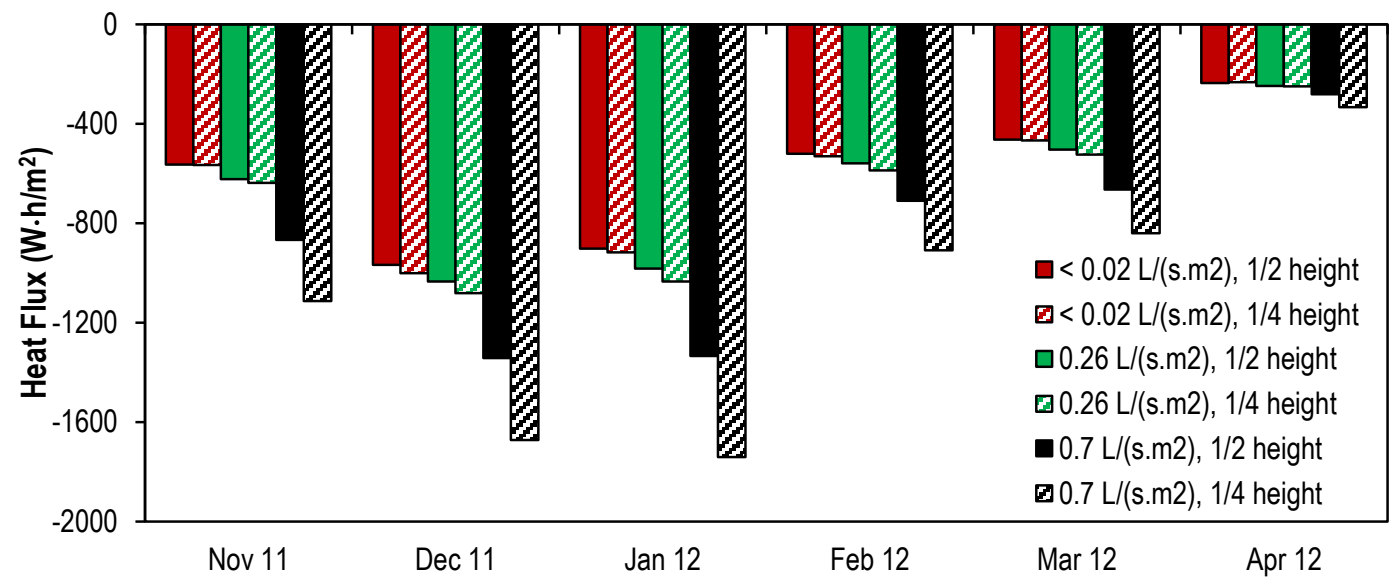

Figure 14. Heat flux at $1 / 4$ height and $1 / 2$ height of the Group 4 panels during the heating season and infiltration.

b. Fluxes were measured between the facing of the fiberglass insulation and the interior drywall.

c. Air leakage rates shown were measured at $\triangle \mathrm{P}=75 \mathrm{~Pa}$. 
Table 6. Monthly increases in heat flux in Group 4 panels due to infiltration.

\begin{tabular}{|c|c|c|c|c|c|c|c|}
\hline \multirow{2}{*}{ Compared air leakage levels } & \multirow{2}{*}{ Sensor location } & \multicolumn{6}{|c|}{$\%$ Increase in Heat Flux } \\
\hline & & Nov & Dec & Jan & Feb & Mar & Apr \\
\hline Level 3 vs. Level 1 & & 54 & 39 & 48 & 37 & 44 & 19 \\
\hline Level 3 vs. Level 2 & $1 / 2$ height & 39 & 30 & 36 & 27 & 32 & 14 \\
\hline Level 2 vs. Level 1 & & 11 & 7 & 9 & 7 & 9 & 5 \\
\hline Level 3 vs. Level 1 & & 97 & 67 & 90 & 71 & 80 & 43 \\
\hline Level 3 vs. Level 2 & $1 / 4$ height & 75 & 55 & 68 & 55 & 60 & 33 \\
\hline Level 2 vs. Level 1 & & 13 & 8 & 13 & 11 & 12 & 8 \\
\hline
\end{tabular}

January data were plotted in Figure 15 to provide more details on the effects that wind has on infiltration/exfiltration and heating loads. Figures 15A and 15B illustrate the correlation between the south winds and the windward pressure on the south side of the test facility, as well as between the north wind and the leeward pressures. $\mathrm{HF}_{1 / 4}$ data in Figure $15 \mathrm{C}$ demonstrates how infiltration and exfiltration influence heat flux. For example, south winds were dominant from late afternoon on January $16^{\text {th }}$ until late at night on the $17^{\text {th }}$. The average south wind speed and outdoor-to-indoor pressures during this period were $5.5 \mathrm{~m} / \mathrm{s}$ and $22 \mathrm{~Pa}$, respectively. These pressures led to infiltration loads that caused the average $\mathrm{HF}_{1 / 4}$ data from the Level 3 wall to be three times higher than the heat fluxes from the Level 1 specimen and two times higher than those from the Level 2 panel (Figure 16A). The average indoor-to-outdoor temperature differential during this period was $16.6^{\circ} \mathrm{C}$.

Effects from exfiltration are demonstrated with data from January $18^{\text {th }}$. During this date, north winds averaging $4.3 \mathrm{~m} / \mathrm{s}$ yielded average leeward pressures of $18 \mathrm{~Pa}$. Because the indoor temperature was about $24^{\circ} \mathrm{C}$ higher than outdoors, exfiltration warmed the cavities of the leakier walls as shown by the temperatures collected between the fiberglass insulation and its facing that are plotted in Figure 17. Consequently, during this period the heat flux between the fiberglass facing and the interior drywall in the Level 3 wall was lower than in the Level 1 and 2 panels (Figure 16B). These data illustrate the heat recovery within wall cavities that is theoretically described by Sherman and Walker (2001). 

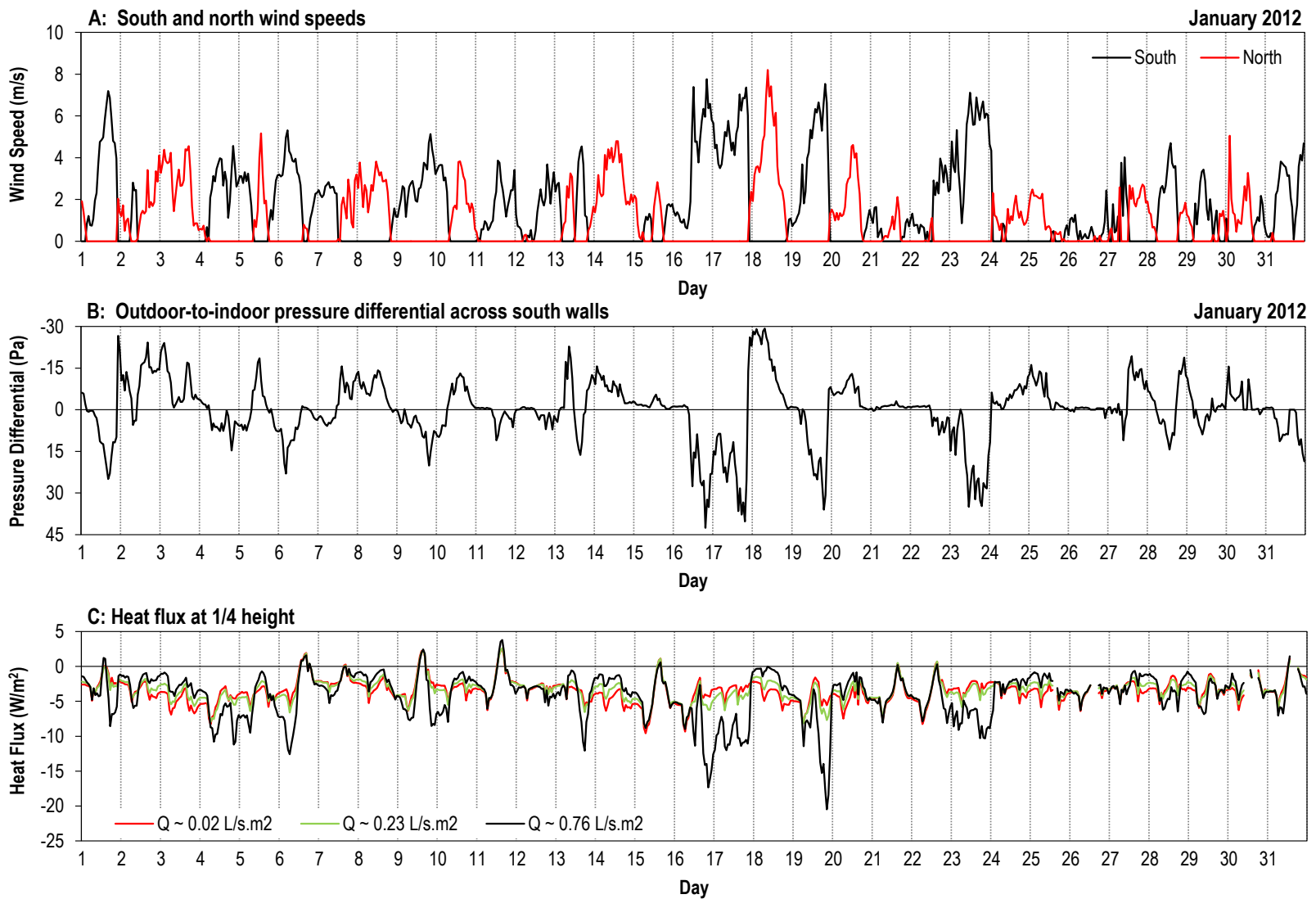

Figure 15. January measurements. A: South and north wind speeds; B: Outdoor-to-indoor pressure differentials (positive values $=\mathrm{P}_{\text {out }}>\mathrm{P}_{\text {in }}$ ); C: Heat flux from Group 4 walls measured between facing of fiberglass insulation and interior drywall and at $1 / 4$ height of wall.

a. Positive pressure differentials indicate that outdoor pressure was higher than indoor pressure.

b. Air leakage rates were measured at $\Delta \mathrm{P}=75 \mathrm{~Pa}$.
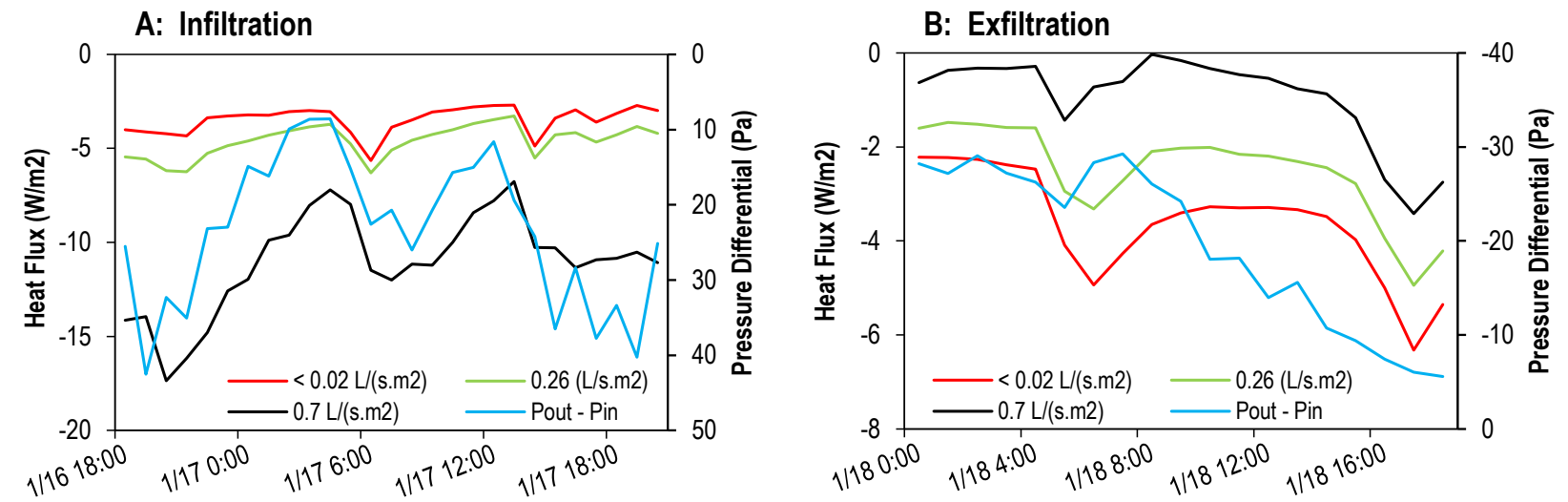

Figure 16. Heat fluxes between facing of fiberglass insulation and interior drywall of the Group 4 walls. A: Effect of infiltration on heat flux. B: Effect of exfiltration on heat flux.

a. Positive pressure differentials indicate that outdoor pressure was higher than indoor pressure.

b. Air leakage rates were measured at $\Delta \mathrm{P}=75 \mathrm{~Pa}$. 


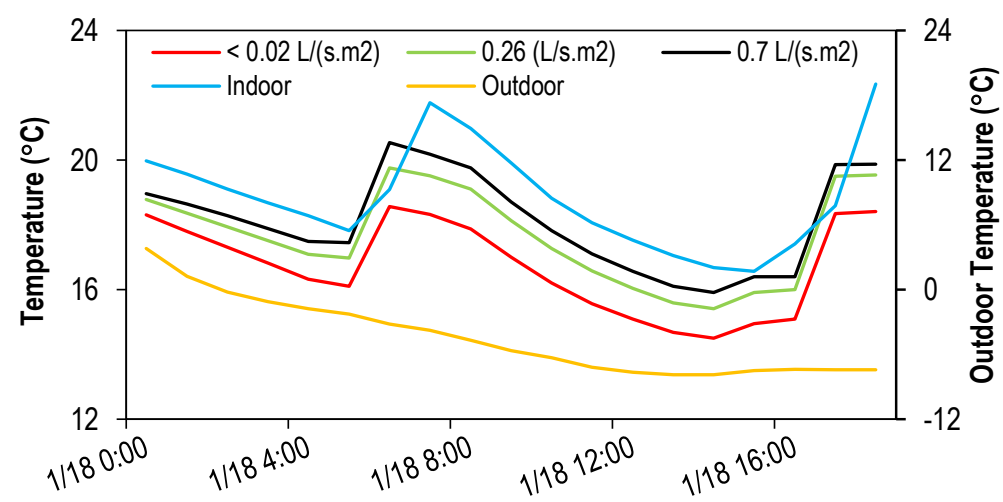

Figure 17. Temperatures measured between the fiberglass insulation and its facing in the Group 4 walls while under leeward pressure.

a. Positive pressure differentials indicate that outdoor pressure was higher than indoor pressure.

\subsection{Moisture within the cavity of test walls}

Various parameters were examined to determine if conditions within wall cavities were suitable for potential moisture problems. More specifically, temperature $\left(\mathrm{T}_{\mathrm{ext} \text { sheath }}\right)$, relative humidity $\left(\mathrm{RH}_{\text {ext sheath }}\right)$, humidity ratio $\left(\mathrm{HR}_{\text {ext sheath }}\right)$ and water vapor pressures $\left(\mathrm{WVP}_{\text {ext sheath }}\right)$ at the inner surface of the exterior sheathing were examined because this location is prone to conditions that are conducive to mold growth. Favorable mold growth conditions generally involve monthly average temperatures that are higher than $5^{\circ} \mathrm{C}$ and relative humidity values that are greater than $80 \%$, although these will vary depending on the host material or substrate.

Figure 18 shows that the monthly average $\mathrm{T}_{\text {ext sheath }}$ data followed outdoor temperature trends: lowest in January and highest in July. January averages in the east and north-facing walls ranged from 7.2 to $8.8^{\circ} \mathrm{C}$, while the south-facing panels had warmer temperatures $\left(\sim 9.5^{\circ} \mathrm{C}\right)$ because of their higher exposure to solar radiation. The Group 1 wall temperatures of $\sim 17^{\circ} \mathrm{C}$ were closest to indoor conditions $\left(\sim 20^{\circ} \mathrm{C}\right)$ because their exterior continuous insulation $(7.6 \mathrm{~cm}$ closed-cell foam) had an R-value that was about 3 times greater than in the other wall groups $(3.8 \mathrm{~cm}$ XPS rigid foam). Figure 18 indicates that the exterior continuous insulation helped maintain $\mathrm{T}_{\text {ext sheath }}$ above $5^{\circ} \mathrm{C}$ in all the test walls, and therefore, warm enough to allow potential mold growth. 

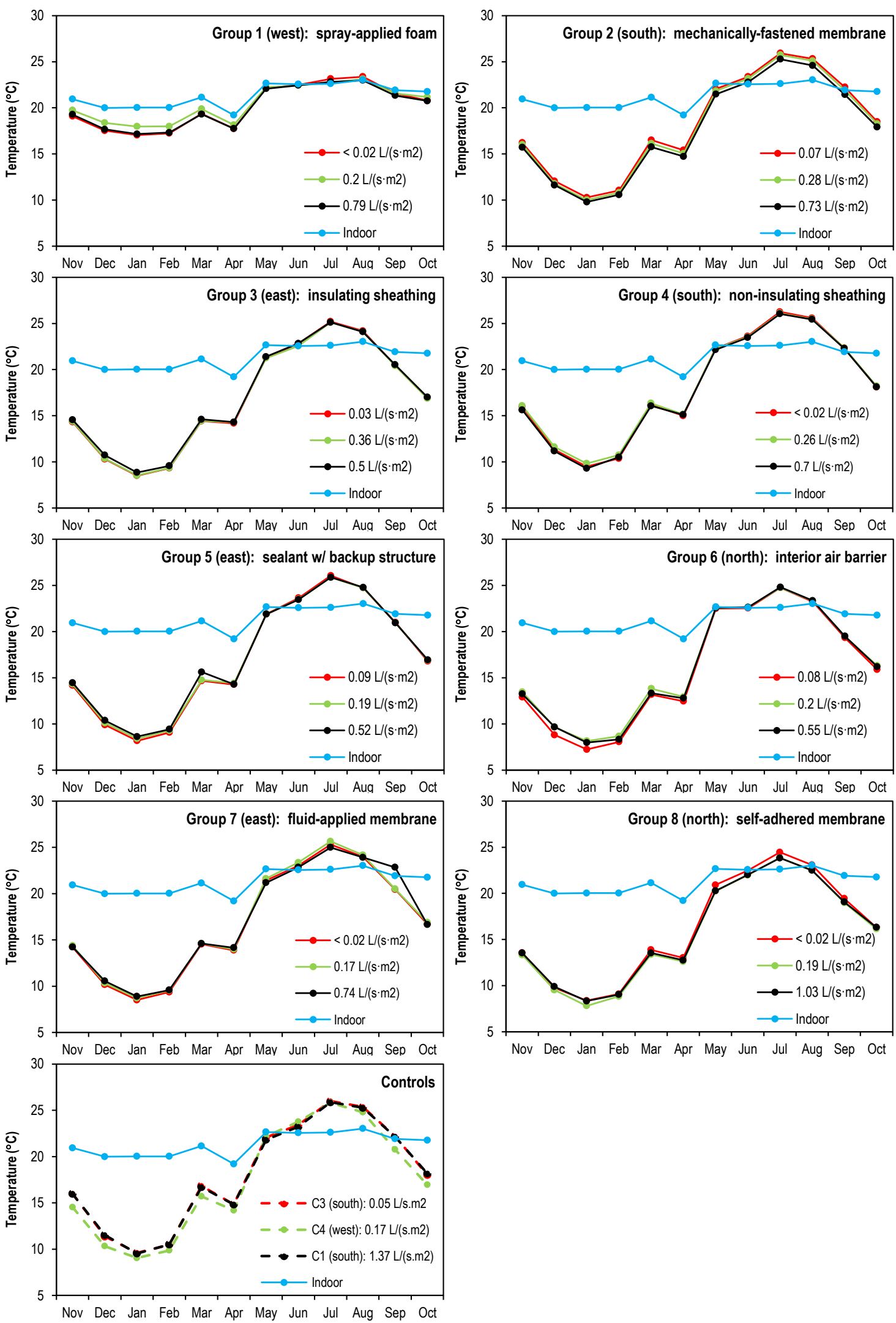

Nov Dec Jan Feb Mar Apr May Jun Jul Aug Sep Oct

Figure 18. Monthly average temperatures at the inner surface of exterior sheathings.

a. Air leakage rates shown were measured at $\triangle \mathrm{P}=75 \mathrm{~Pa}$. 
Figure 19 shows the monthly average humidity ratios $\left(\mathrm{HR}_{\mathrm{ext}}\right.$ sheath $)$ and water vapor pressures $\left(\mathrm{WVP}_{\text {ext sheath }}\right)$ at the inner surface of the exterior sheathings of all walls, as well as the measurements gathered within the facility $\left(\mathrm{HR}_{\mathrm{in}}, \mathrm{WVP}_{\text {in }}\right)$. In general, $\mathrm{HR}_{\text {ext sheath }}$ tracked $\mathrm{HR}_{\mathrm{in}}$ : increased as the months progressed from winter to summer, and decreased from summer to fall. Indoor parameters were in turn influenced by outdoor conditions (Figure 11), as well as by the $40 \%$ setting in the humidifier that was used during the winter. Other general patterns include that the Level 1 panels in each of the groups generally had higher monthly average $\mathrm{HR}_{\text {ext sheath }}$ measurements during the winter than the Level 2 and Level 3 walls because they lacked flow of relatively dry outdoor air to help decrease water vapor within the cavity. Instead, the Level 1 specimens depended on diffusion for moisture removal. Furthermore, when these tightly-built walls were facing east, west or north, they received minimal winter insolation and could not benefit from solar-driven water vapor diffusion. However, as outdoor water vapor increased from winter to summer, infiltration raised humidity ratios in the leakier panels at a faster rate

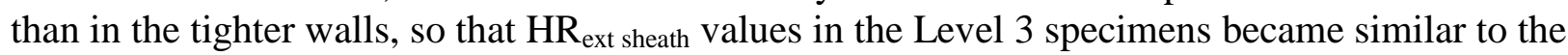
ratios in the Level 1 walls.

Construction materials also affected the humidity ratio within the wall cavities. Figure 20A

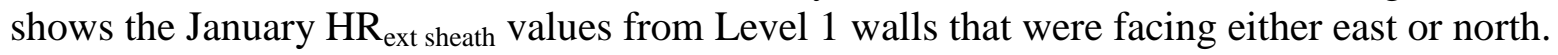

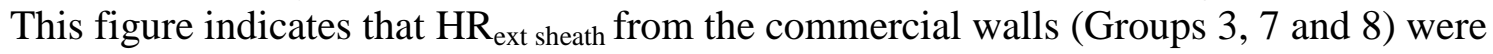
somewhat similar, and about $15 \%$ higher than the measurements from the residential wall (Group 5). This $15 \%$ difference was also observed in the south-facing Level 1 walls per Figure 20B, where the Group 2 and 4 panels represented commercial and residential construction, respectively.

A main difference between the commercial and the residential walls is the moisture capacity of the materials in the wall cavities. Commercial walls had light gage steel framing and either glass mat gypsum (Groups 1, 2, 7 and 8) or XPS rigid insulation (Group 3) as the exterior sheathing. Residential panels used wood stud framing and oriented strand board (OSB) sheathing. The sorption isotherms for glass mat gypsum (GMG) and OSB sheathings in Figure 21 were collected per ASTM C 1498-04a, and these reveal that the moisture that can be stored in OSB is about an order of magnitude higher than what GMG sheathing allows. Sorption data for XPS foam boards are expected to be lower than those from GMG. Consequently, the sorption isotherms explain the observed trends: the capacity of wood to store water vapor helped

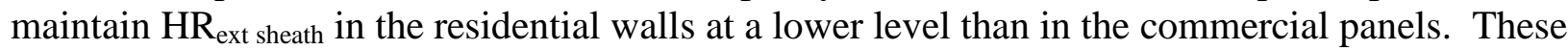
findings demonstrate comments by Straube (2001) about potential disadvantages from using materials with low moisture storage capacity. Therefore, these results imply that buildings that are located in cold climates and that have envelope materials with low moisture capacity, can be susceptible to moisture problems. These potential problems can be diminished by controlling indoor moisture sources in the winter. 

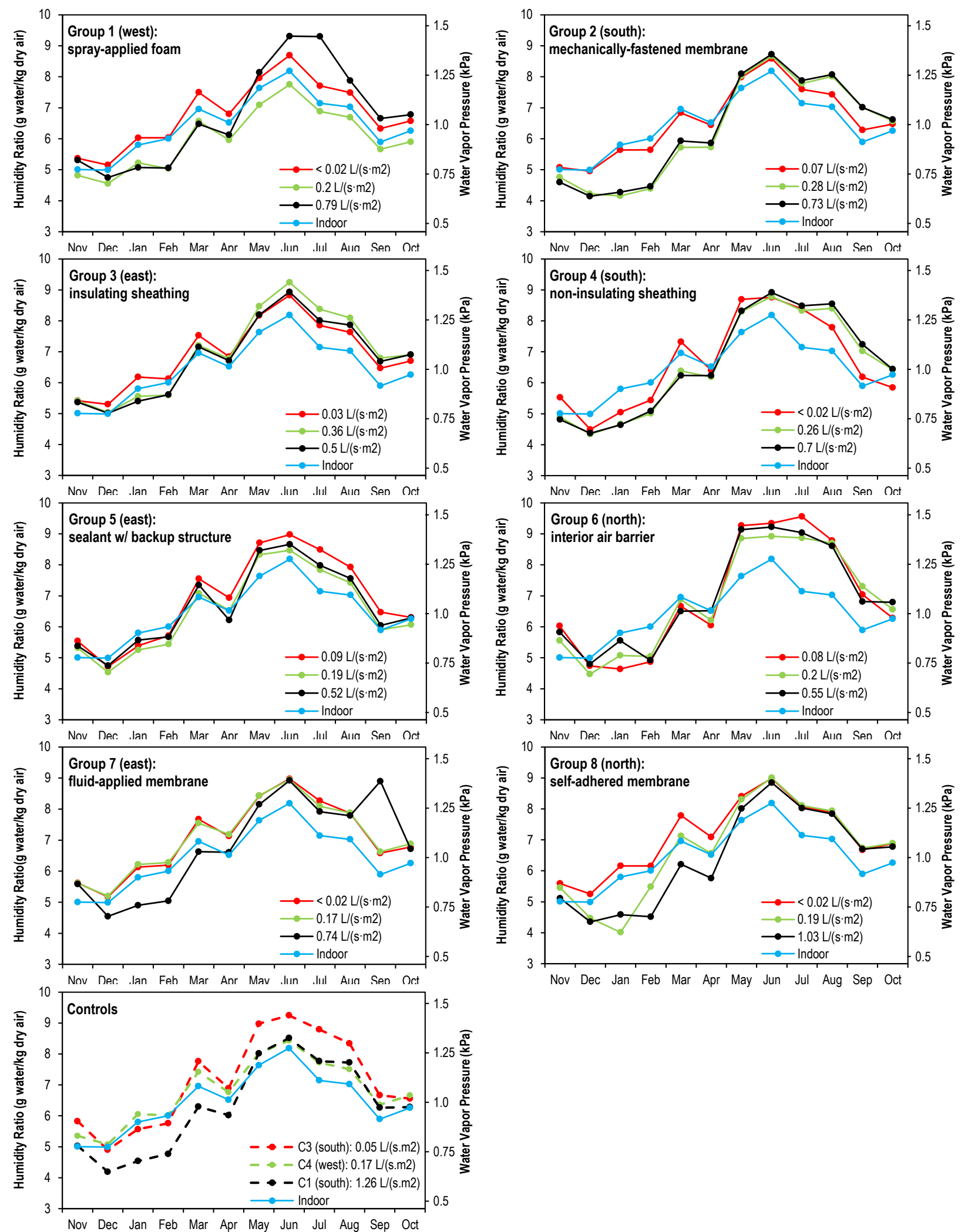

Figure 19. Monthly average humidity ratio and water vapor pressure at the inner surface of exterior sheathings.

a. Air leakage rates shown were measured at $\triangle \mathrm{P}=75 \mathrm{~Pa}$. 


\section{A: East and north-facing walls}

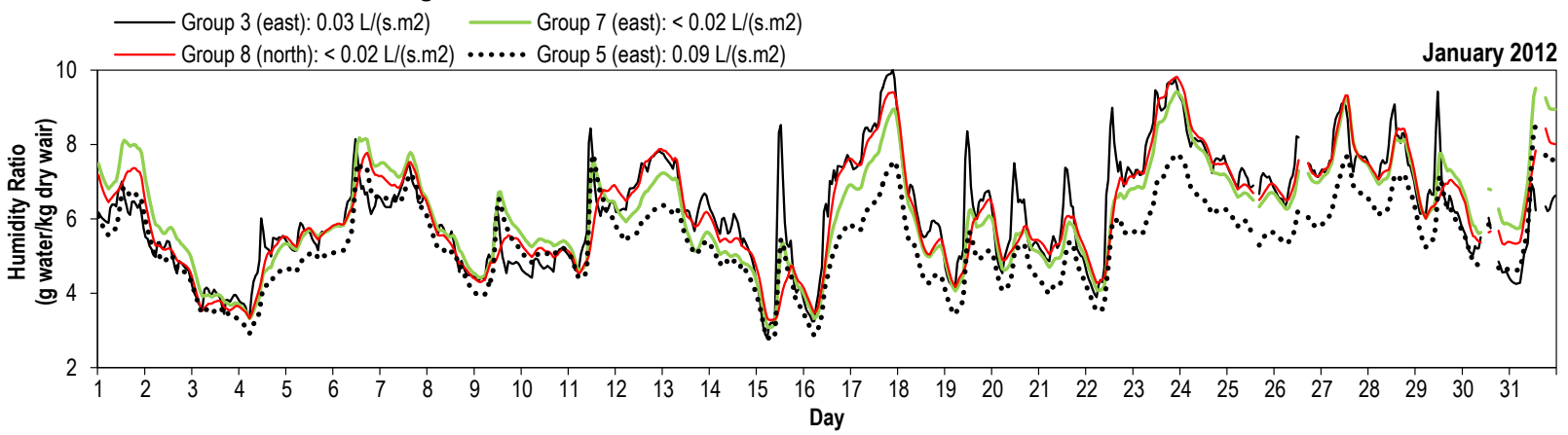

B: South-facing walls

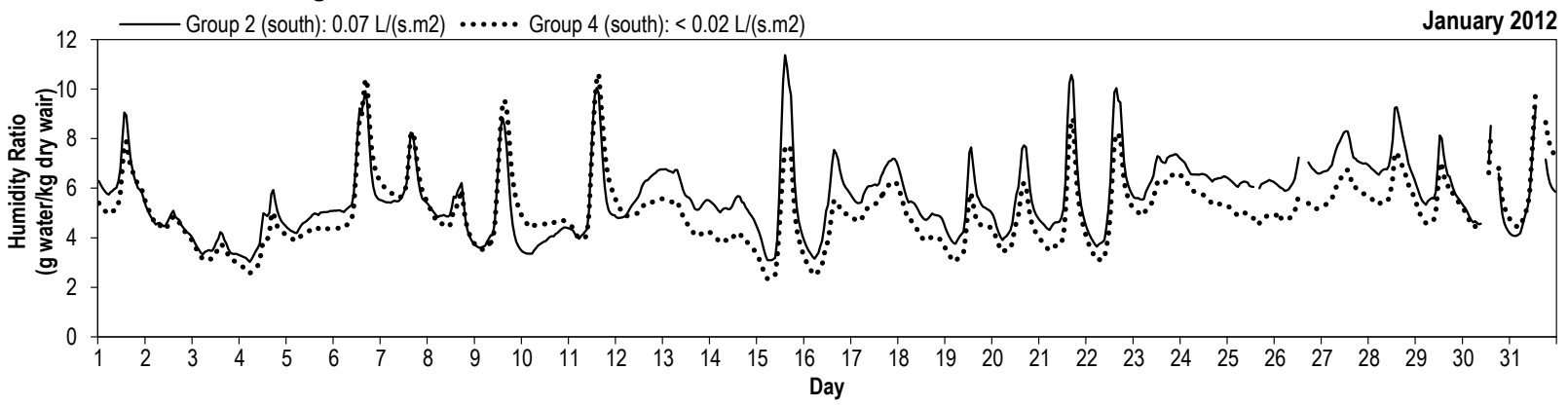

Figure 20. January hourly average humidity ratio at the inner surface of exterior sheathings in Level 1 walls. A: East and north-facing walls: Groups 3, 5,7 and 8. B: South-facing walls: Groups 2 and 4.

a. Air leakage rates shown were measured at $\triangle \mathrm{P}=75 \mathrm{~Pa}$.

b. Walls from Groups 2, 3, 7 and 8 were built with materials used in commercial construction: steel framing and glass mat gypsum or XPS rigid insulation (Group 3) as the exterior sheathing. Walls from Groups 4 and 5 were framed with wood to simulate residential construction.

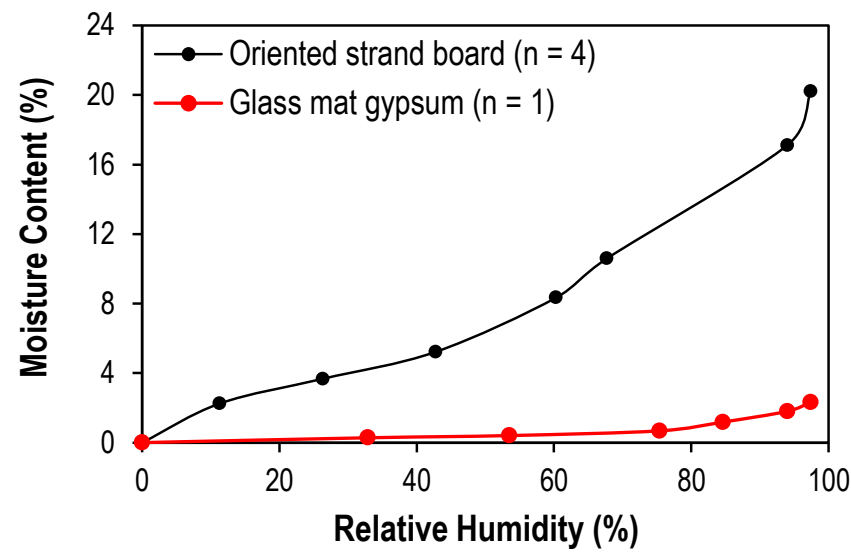

Figure 21. Adsorption isotherms of oriented strand board sheathing and glass mat gypsum sheathing. a. Average from four oriented strand board sheaths.

Figure 22 describes the monthly average relative humidity at the inner surface of the exterior

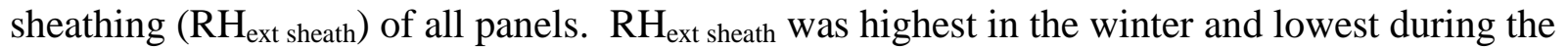
summer in all walls, which is expected given the aforementioned temperature and humidity ratio

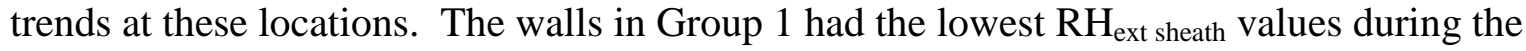
heating season because of the higher R-value of its exterior insulation. The Level 1 panels 
generally had the highest monthly average $\mathrm{RH}_{\text {ext sheath }}$ winter data because, as it was previously pointed out, these walls lacked the flow of relatively dry outdoor air that removed water vapor from the stud cavity of the Level 2 and Level 3 specimens.

According to Figure 22, the Level 1 panels in Groups 3, 7 and 8 had average $\mathrm{RH}_{\text {ext sheath values }}$ for the months of January and February that were higher than $80 \%$. Therefore, these walls may have had adequate conditions for mold growth in their stud cavities. Figure 23 provides a closer look at the January and February $\mathrm{RH}_{\text {ext sheath }}$ data of these Level 1 walls. Condensation occurred in the Group 3 wall for about a third of the month in January. During these same dates,

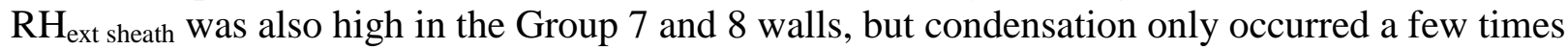
in the Group 8 panel. In February, condensation was much less frequent than in January. For comparison purposes, Figure 23 also shows measurements from the Group 5, Level 1 wall and indicates that it had RH values that were about $10 \%$ lower than in the previously described test specimens because its wood-frame construction stored moisture that dampened increases in humidity.

The potential for mold growth in the east and north facing walls was investigated further using more detailed criteria per Sedlbauer (2002). January and February hourly average values for $\mathrm{T}_{\text {ext sheath }}$ and $\mathrm{RH}_{\text {ext sheath }}$ were plotted against WUFI-generated lowest isopleths for mold (LIM) growth in Figure 24. Conditions above these isopleths indicate that mold growth may be possible, but additional evaluations are required to reach a more decisive conclusion. These isopleths are dependent on temperature and the hosting material or substrate. The two commonly studied groups of substrates are:

- LIM B I: biologically recyclable building materials like wall paper, paper facings on gypsum board, building materials made of biologically degradable raw materials, material for permanent caulking.

- LIM B II: building materials with porous structure such as renderings, minerals building materials, certain wood species as well as insulation material not covered by LIM B I.

Figure 24 suggests that the Level 1 walls from Groups 3, 7 and 8 showed potential for mold growth. In contrast, the Group 5 wall had a lower likelihood for mold occurrence primarily because the higher moisture capacity of its wood members dampened $\mathrm{RH}_{\text {ext sheath. Figure } 25}$ shows similar plots for the remaining Level 1 panels. Data from the Group 1 and Group 4 walls indicate that mold problems are unlikely in their stud cavity because of their warmer temperature: the former had a high R-value exterior continuous insulation and the latter was facing south, which facilitated solar-driven vapor diffusion indoors. Additionally, the Group 4 panel was wood framed. Although the Group 2 wall was framed with materials that had a low moisture capacity, its south orientation regulated the temperature and the amount of moisture in the stud cavity. The Group 6 panel did not appear hospitable to mold because it was wellcoupled to the relatively dry, winter, outdoor air given that the air barrier was located on the inner side of the stud cavity. This placement of the air barrier decreased the drying potential toward the inside of the facility. However, condensation and mold growth did not occur during the summer in the Group 6, Level 1 wall because the relative humidity on the outer surface of the indoor air barrier remained below $65 \%$. 

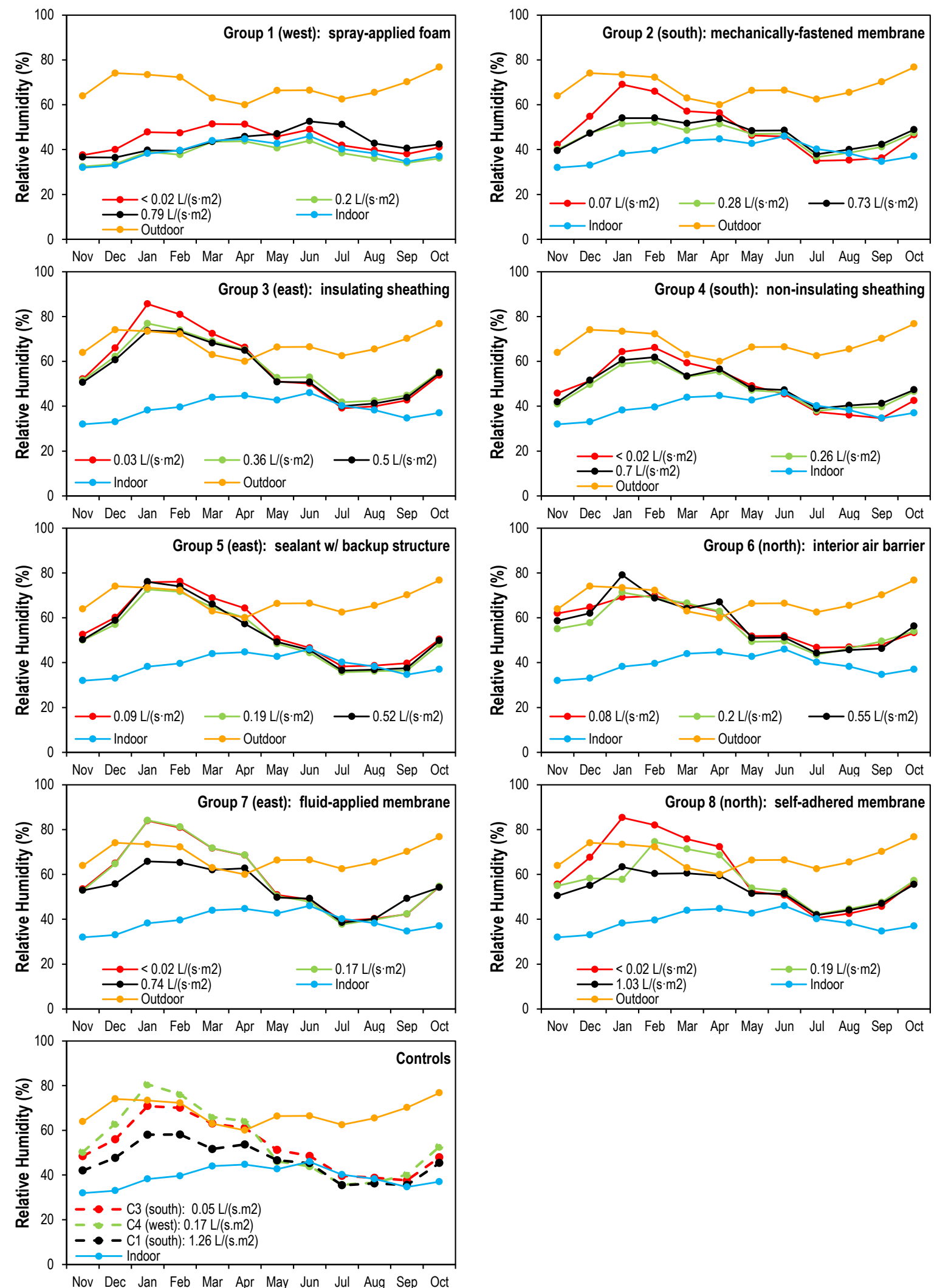

Figure 22. Monthly average relative humidity at the inner surface of exterior sheathings.

a. Air leakage rates shown were measured at $\triangle \mathrm{P}=75 \mathrm{~Pa}$. 

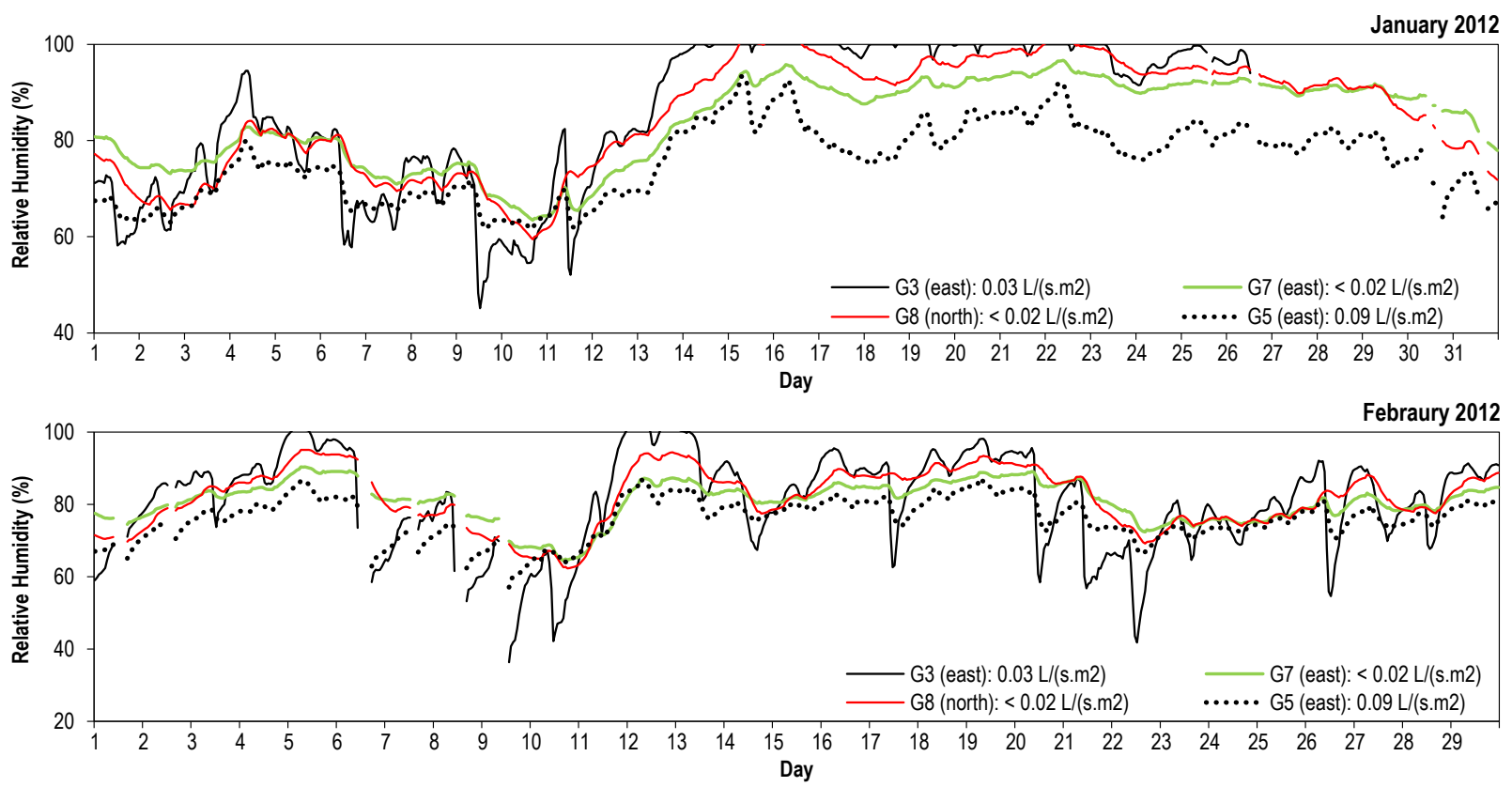

Figure 23. January hourly average relative humidity at the inner surface of the exterior sheathings in the Group 3, 5, 7 and 8 panels.

a. Air leakage rates shown were measured at $\triangle \mathrm{P}=75 \mathrm{~Pa}$.

b. Walls from Groups 3,7 and 8 were built with materials used in commercial construction: steel framing and glass mat gypsum or XPS rigid insulation sheathing. Wall from Group 5 was framed with wood to simulate residential construction.
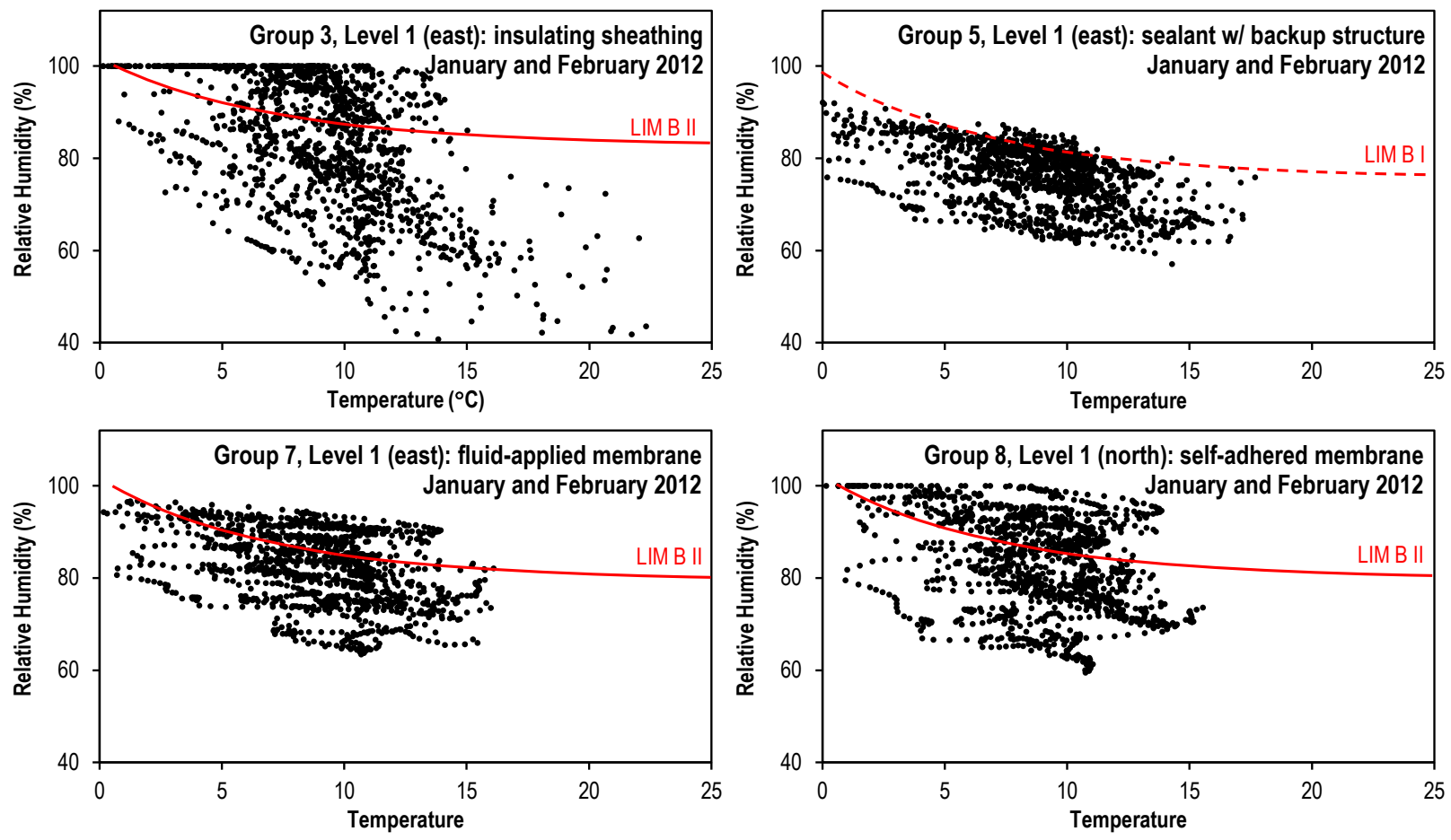

Figure 24. January and February hourly averages from Level 1 walls in Groups 3, 5, 7 and 8 with respect to the lowest isopleth for mold growth on organic substrates (LIM B I) and inorganic substrates (LIM B II). 

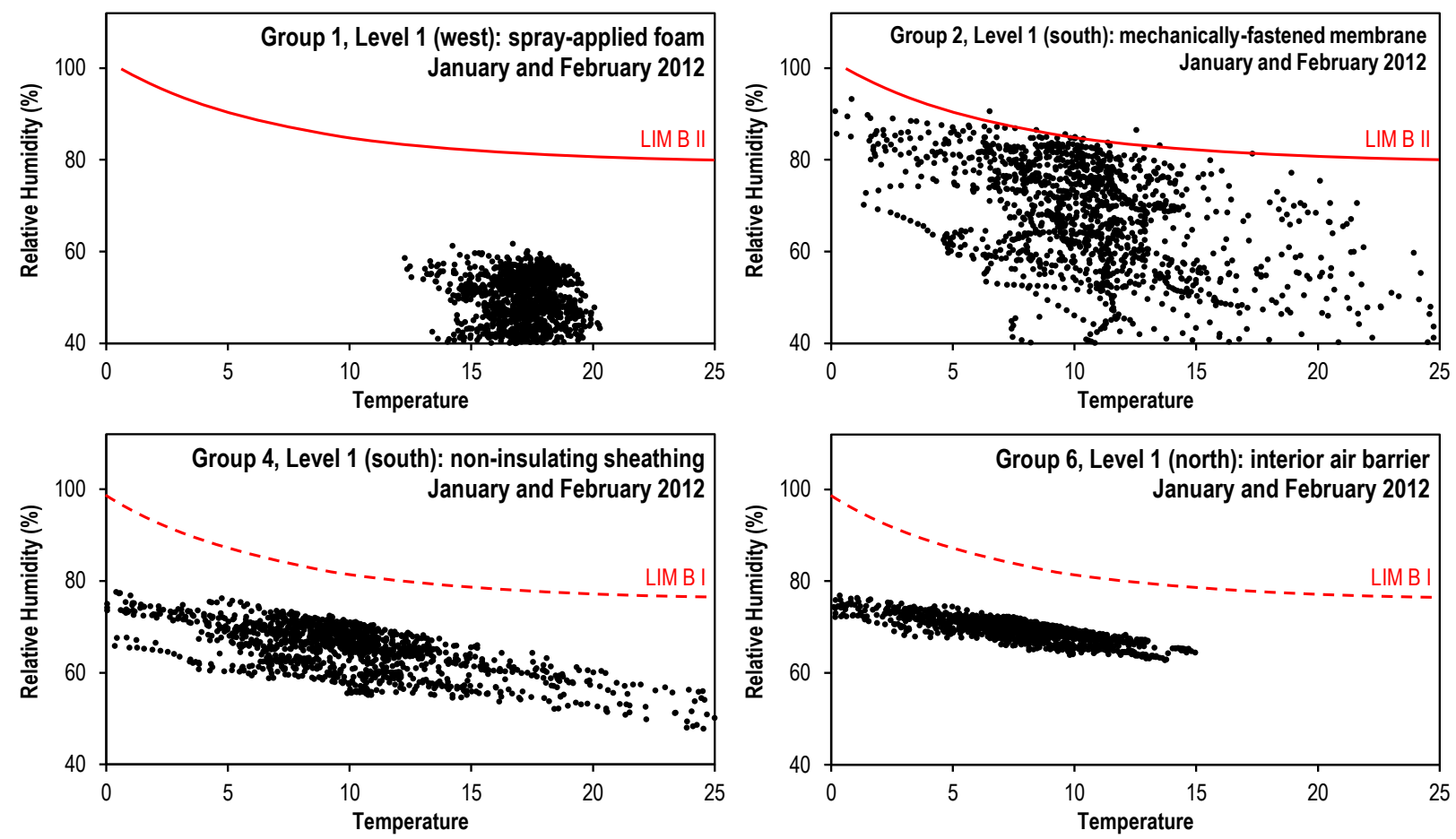

Figure 25. January and February hourly averages from Level 1 walls from Groups 1, 2, 4 and 6 with respect to the lowest isopleth for mold growth on organic substrates (LIM B I) and inorganic substrates (LIM B II).

\section{Conclusions}

The relative contribution of air leakage to HVAC loads increases as insulation in the building envelope increases. Test walls with an R-value of $3.7 \mathrm{~K} \cdot \mathrm{m}^{2} / \mathrm{W}\left(\mathrm{R}_{\mathrm{US}}=21 \mathrm{~h} \cdot \mathrm{ft}^{2} \cdot{ }^{\circ} \mathrm{F} / \mathrm{Btu}\right)$ were evaluated in a DOE zone 5 climate. Winter heat fluxes through walls that were facing dominant winds were reduced on average by about $40 \%$ by decreasing air leakage from 0.7 to 0.02 $\mathrm{L} /\left(\mathrm{s} \cdot \mathrm{m}^{2}\right)$ at $75 \mathrm{~Pa}$. This reduction was approximately $30 \%$ when airtightness was improved from 0.7 to $0.2 \mathrm{~L} /\left(\mathrm{s} \cdot \mathrm{m}^{2}\right)$ at $75 \mathrm{~Pa}$. These results indicate that further decreases to the $2012 \mathrm{IECC}$ air leakage requirement of $2 \mathrm{~L} /\left(\mathrm{s} \cdot \mathrm{m}^{2}\right)$ for building enclosures could potentially contribute to significant energy savings. However, improvements in airtightness need to be accompanied by proper designs because these walls could be more susceptible to mold growth. Important factors that can influence the likelihood of mold growth in tightly-built walls are indoor moisture sources, the moisture capacity of materials in the wall cavity, the thermal resistance of continuous exterior insulation, and the amount of winter solar radiation on the walls. 


\section{Acknowledgements}

This work was supported by the Assistant Secretary for Energy Efficiency and Renewable Energy, Building Technologies Office Program, U.S. Department of Energy, under Contract No. DE-AC05-00OR22725. Support was also provided by the Air Barrier Association of America (ABAA), Syracuse University and the New York State Energy Research and Development Authority (NYSERDA). Special thanks to Kurt Dalgleish, Mikael Salonvaara and Denis Pradhan for their assistance during the installation of the test walls, and to Kaushik Biswas and Simon Pallin for reviewing this report.

\section{References}

ASHRAE. 2009. ASHRAE Handbook-Fundamentals. Atlanta: American Society of Heating Refrigeration and Air Conditioning Engineers, Inc.

ASHRAE. 2009. ASHRAE Standard 160. Criteria for moisture-control design analysis in buildings. Atlanta: American Society of Heating Refrigeration and Air Conditioning Engineers, Inc.

ASTM International. 2004. ASTM C1498-04a. Standard test method for hygroscopic sorption isotherms of building materials. Pennsylvania: American Society for Testing and Materials International.

ASTM International. 2005. ASTM E2357. Standard test method for determining air leakage of air barrier assemblies. Pennsylvania: American Society for Testing and Materials International.

ASTM International. 2003. ASTM E2178. Standard test method for air permeance of building materials. Pennsylvania: American Society for Testing and Materials International.

Boudreaux PR, Hendrick T, Christian J, Jackson RK. 2012. Deep residential retrofits in East Tennessee. Oak Ridge National Laboratory. Report ORNL/TM-2012/109.

Emmerich SJ, Persily AK. 2005. Airtightness of commercial buildings in the US. In: Proceedings from the $26^{\text {th }}$ Air infiltration and ventilation centre conference.

Emmerich SJ, McDowell TP, Anis W. 2005. Investigation of the impact of commercial building envelope airtightness on HVAC energy use. National Institute of Standards and Technology. NISTIR 7238.

Huang J, Franconi E. 1999. Commercial heating and cooling loads component analysis. Lawrence Berkeley National Laboratory. LBNL 37208.

Huang J, Hanford J, Yang F. 1999. Residential heating and cooling loads component analysis. Lawrence Berkeley National Laboratory. LBNL 44636. 
IECC. 2012. 2012 International Energy Conservation Code. Country Club Hill, IL: International Code Council.

Jackson RK, Kim EJ, Roberts S, Stephenson R. 2012. Advancing residential retrofits in Atlanta. Oak Ridge National Laboratory. Report ORNL/TM-2012/488.

Logue JM, Sherman MH, Walker IS, Singer BC. 2013. Energy impacts of envelope tightening and mechanical ventilation for the US residential sector. Energy and Buildings 65:281-291.

Offerman FJ. 2009. Ventilation and indoor air quality in new homes. California Air Resources Board and California Energy Commission, PIER Energy-Related Environmental Research Program. Collaborative Report. CEC-500-2009-085.

Sedlbauer K. 2002. Prediction of mould growth by hygrothermal calculation. J Bldg Physics 25(4):321-336.

Sherman MH, Walker IS. 2001. Heat recovery in building envelopes. Lawrence Berkeley National Laboratory. LBNL 47329.

Sherman MH, Matson NE. 2002. Air tightness of new US houses: a preliminary report. Lawrence Berkeley National Laboratory. LBNL 48671.

Straube J. 2001. The influence of low-permeance vapor barriers on roof and wall performance. In: Proceedings from the Buildings VIII Conference, Clearwater, FL.

Straube J, Smegal J. 2009 (rev 2012). Building America special research project: high-R walls case study. Prepared by the Building Science Corporation for the Department of Energy, Building America Program.

Swami MV, Chandra S. 1987. Procedures for calculating natural ventilation airflow rates in buildings. Florida Solar Energy Center. FSEC-CR-163-86.

TenWolde A, Carll C. 1992. Effect of cavity ventilation on moisture in walls and roofs. In: Proceedings from the Buildings V Conference, Clearwater, FL.

TenWolde A, Rose WB. 1996. Moisture control strategies for the building envelope. J Thermal Insul Bldg Env 49:206-214.

Tsongas GA, Nelson GD. 1991. A field test for correlation of air leakage and high moisture content sites in tightly built walls. ASHRAE Transactions 97(1).

Wilcox BA, Weston TA. 2001. Measured infiltration reduction in California production houses using housewrap. In: Proceedings from the Buildings VIII Conference, Clearwater, FL.

Zhivov A, Herron D. 2011. Improvement of Air Tightness. J Bldg Enclosure Design 11-13. 